\title{
Doping for Chess Performance
}

\section{Sighart Golf*}

University of Giessen, Institute of Laboratory Medicine and Pathobiochemistry, Germany

\begin{abstract}
During a chess game, the needed energy is first derived instantly from ATP and creatine-phosphate, then within a few seconds later from glycogen stores in brain, glycogen, muscle and liver and finally, 1-2 hours later from adipose tissue. Anaerobic oxidation of glucose-derivative from glycogen delivers energy 6 times faster than aerobic oxidation of glucose and oxidation of fatty acids; correspondingly, mental activity can perform as well 6 times faster as long as glycogen is available.
\end{abstract}

The mental profile of chess players correlates with cerebral processes such as attention, conflict solution, memory, motivation and recognition, which together constitute a specific chess-domain expertise.

A chess player may compete best when a) regularly physical exercise is carried out to compete in strenuous chess tournaments and to stimulate mental cognition, b) super compensated glycogen is accumulated in brain, muscle and liver by corresponding nutrition and physical and mental activities, and c. an active mental disposition is available for complex brain tasks during chess by complementary treatment schemes e.g., cogni-tive enhancement (CE) by chess training with chess boards, chess books, building chess images, visual observation of chess games, vocational training with chess, metacognitive training, and additionally regular light physical stress.

\section{An illicit improvement of brain performance for chess playing may be achieved by several measures:}

1. Increase of $\mathrm{O}_{2}$ supply by therapy with erythropoietin (EPO) for chess tournaments at high altitudes and for chess players with lung diseases

2. Increase of body glycogen by therapy with insulin

3. mental stimulation by caffeine

AAS, anabolic agents, amphetamines, nicotine and cocaine have no proven effect on quality of chess playing. Many steroid- and proteohormones such as cortisol, testosterone, ACTH, EPO, GH, hCG, IGF-I, Insulin, LH, present positive effects on brain development and cognition only when present in natural concentrations during development of brain. Pharmaceutical preparations show positive effects only at low baseline cognition. With elevated concentrations, these hormones present negative effects on mental cognition.

Actual CE drugs have effects only with persons at low cognitive baseline. With normal persons, CE is still below clinical significance.

Regular non-medical use of steroid and proteohormones in elevated concentrations and CE-drugs must also consider numerous side effects ranging from simple metabolic disturbances through cardiac problems to cognitive decline to tumorgenesis and sudden death.

\section{Keywords: Chess; Doping}

\section{Introduction}

Chess is officially recognized as sport by the IOC. Several national chess organizations however, such as the DSB (German Chess Organization) in Germany and the Chess Federation of Canada fall outside sport organizations for funding and are therefore practically excluded from official financial support [1]. In order to obtain and thereafter maintain that recognition as sport the DSB has to adopt the national as well as the Olympic anti-doping policy.

Doping is an area of ongoing public, legal, and medical debate and in recent years it has been reported to be connected with many sports including athletics, cycling, body building, soccer, swimming [2] and recently also with chess [3]. According to Dekhuijzen [2] there are five prohibited classes of substances: stimulants, narcotics, anabolic agents, diuretics, and peptide and glycoprotein hormones and their analogues. Doping classes should be classified preferably by desired effects on energy availability, muscle performance, respiratory and renal system and mental performance.

The first chess-doping scandal happened on the last day of the Chess Olympiad in November 2008 in Dresden. Who knows what was going through Iwanchuk's head (actually $4^{\text {th }}$ on world chess ranking list 2014), when on Nov. 25 in Dresden, the last day of the Chess Olympiad, a judge asked Iwanchuk to submit to a drug test. Iwanchuck stormed out of the room in the conference center, kicked a concrete pillar in the lobby, pounded a countertop in the cafeteria with his fists and then vanished into the locker-room [3].

Especially in chess, doping tests are usually characterized as a joke, a waste of time and money.

Are doping tests justified for chess players?

*Corresponding author: Sighart Golf, University Medical School, University of Giessen, Institute of Laboratory Medicine and Pathobiochemistry, Rimbergstrasse 9, Biebertal, 06409, Germany, Tel: 004964093066; E-mail: Sighart.Golf@ klinchemie.med.uni-giessen.de

Received March 09, 2015; Accepted April 17, 2015; Published April 21, 2015

Citation: Golf S (2015) Doping for Chess Performance. J Sports Med Doping Stud 5: 160. doi:10.4172/2161-0673.1000160

Copyright: (c) 2015 Golf S, et al. This is an open-access article distributed under the terms of the Creative Commons Attribution License, which permits unrestricted use, distribution, and reproduction in any medium, provided the original author and source are credited. 


\section{Metabolic and Mental Requirements for Doping in Chess}

When a competitive chess player considers to increase physical and mental disposition for successful chess playing performance before a chess competition, which of the body functions should be increased?

\section{Chess players need for successful professional chess competitions}

Physical endurance instead of maximal physical performance for chess tournaments lasting for days or weeks: Physical exercise should be carried out on the oxidative level to strengthen the cardio-respiratory system $[4,5]$ and prepare the brain to respond to cognitive stimulation [6]. A cognitive training then induces neuronal changes in specific networks associated with the trained skill.

Oxygen $\left(\mathrm{O}_{2}\right)$ needed for brain energy derived from ATP coming from glucose, glycogen and fat metabolism: $\mathrm{O}_{2}$ is taken up by lungs and transported to cells via the erythrocytes (Ery). The $\mathrm{O}_{2}$-concentration in the Ery is usually expressed as oxygen saturation, which is found in arterial blood between $94-98 \%$ and in venous blood between $80-85 \%$. It can be measured by blood-gas analyzers. During physical exercise, $\mathrm{O}_{2}$ is taken up from Ery by muscle cells to produce energy. At the same time, new $\mathrm{O}_{2}$ enters the body by the lungs. In strenuous exercises with a heavy workload, $\mathrm{O}_{2}$-consumption in muscle cells exceeds $\mathrm{O}_{2}$-uptake by lungs and $\mathrm{O}_{2}$-saturation in Ery consequently decreases [7]. Since the physical workload during a chess game or a chess tournament is normally within $\mathrm{O}_{2}$-balance, a decrease of $\mathrm{O}_{2}$ saturation in Ery will happen most unlikely.

Replenished glycogen-stores in brain, liver and muscle: The adult brain relies on glucose for its energy needs and stores it in the form of glycogen, primarily in astrocytes. Animal and cell-culture studies indicate that brain glycogen supports neuronal function when the glucose supply from blood is inadequate or during neuronal activation [8]. Human brain glycogen content is estimated at $\sim 3.5 \mu \mathrm{mol} / \mathrm{g}$, i.e., three- to fourfold higher than free glucose at euglycemia [9].

While availability of fat in humans is relatively constant, ATP, creatine-phosphate $(\mathrm{CP})$, glucose and glycogen stores in humans change rapidly during physical and mental strain. During mental exercise such as chess as well as physical exercise, energy is used according to availability with respect to delay time, velocity of resynthesis and total quantity. The corresponding data are listed in (Table 1).

Amounts of substrate available, delay time of production and maximal rates of production in a $70 \mathrm{~kg}$ man (estimated muscle mass $28 \mathrm{~kg}$ ), in parts completed and normalized. Glycogen and glycogen metabolism in brain were calculated from brain weight [12] and glycogen content in brain [9].

In addition to the primary availability of human energy resources (Table 1), production of glycogen from glucose is also a rapid process starting at the beginning of glycogen use by mental and physical activity. Glycogen is resynthesised within 40 minutes [13].

It becomes clear from these data, that energy production from glycogenolysis necessary for mental or physical work delivers ATP within 5-10 seconds, in contrast to energy from fatty acids in more than 5000 seconds. In addition, glycogen is continuously and rapidly resynthesised as long as glucose is available. Secondly, rate of ATPproduction from anaerobic glycolysis is at least 6times faster than from oxidation of fatty acids and 3times faster than oxidation of glucose.
In conclusion, mental activity during chess games or physical exercise can only function at highest performance when glycogen is still present in sufficient amounts. When glycogen stores are expended, brain "talks" to adipose tissue [14], which then delivers energy from fatty acid oxidation. Mental and physical performance speed decreases now and mental and physical performance declines cumulatively and finally fatigue occurs.

Active mental disposition for complex brain tasks during chess: Chess players have no exceptional intellectual abilities. Chess expertise can be best predicted by a domain specific practice.

$\mathrm{CE}$ for chess playing and of course for mental performance in physical sport in a natural setting can also be achieved by numerous natural molecules present in humans, such as insulin, growth-hormone (GH), Insulin-like-growth factor-1 (IGF-1), testosterone and estradiol. Especially diabetic persons are at the receiving end of insulin deficiency concerning mental disposition [15].

Many of these molecules are also available for medical therapy but also for unethical use to achieve improved mental and athletic performance.

In addition to natural proteo and steroid hormones numerous drugs have been synthesised with the aim, to enhance cognition for medical therapy of brain disabilities, such as narcolepsy, dementia, Alzheimer's disease (AD), Parkinsons disease (PD), schizophrenia or attention deficit hyperactivity disorder (ADHD) and depression [16].

\section{Substances Suited for Doping in Chess}

\section{Androgenic Anabolic Substances (AAS)}

Natural steroids: Mother substance to all natural steroid hormones, such as testosterone, estradiol, cortisol and aldosterone, is cholesterol. On the metabolic pathway from cholesterol to the gonadal and adrenal hormones, numerous steroid metabolites such as dehydroepi-androsterone-sulfate (DHEAS) appear. In addition, Testosterone is further metabolized by enzymatic reactions, so that many steroid metabolites appear in the human body, which present all or only part of the properties of testosterone (26 in the WADA-List from 2014). In addition, testosterone analogues are synthesized by chemical reactions (44 in the WADA-list from 2014), which are not present in the human body, but have all or only some properties of testosterone.

In this work, the author concentrates therefore on the effects of

\begin{tabular}{|c|c|c|c|}
\hline $\begin{array}{l}\text { Energy Derived } \\
\text { from }\end{array}$ & $\begin{array}{l}\text { Maximal Rate of } \\
\text { ATP Synthesis } \\
\text { (mmol ATP/min) }\end{array}$ & Delay Time & $\begin{array}{c}\text { Amount Available } \\
\text { (mol) }\end{array}$ \\
\hline Fatty acids $\rightarrow \mathrm{CO}_{2}$ & 0.4 & $>2 \mathrm{~h}$ & 4000 \\
\hline $\begin{array}{l}\text { Glucose from } \\
\text { blood } \rightarrow \text { lactate }\end{array}$ & 2.35 & approx. $90 \mathrm{~min}$ & 0.11 \\
\hline $\begin{array}{c}\text { Muscle } \\
\text { glycogen } \rightarrow \text { lactate }\end{array}$ & 2.35 & $5-10 \mathrm{sec}$ & 6.7 \\
\hline $\begin{array}{c}\text { Muscle glycogen } \\
\rightarrow \mathrm{CO}_{2}\end{array}$ & $0.85-1.14$ & several min & 84 \\
\hline $\begin{array}{c}\text { Liver } \\
\text { glycogen } \rightarrow \mathrm{CO}_{2}\end{array}$ & 0.37 & several min & 19 \\
\hline \begin{tabular}{|c} 
Brain \\
glycogen $\rightarrow$ lactate
\end{tabular} & 2.35 & $5-10 \mathrm{sec}$ & 0.5 \\
\hline Glycolysis $\rightarrow$ lactate & 2.35 & $5-10 \mathrm{sec}$ & 6.7 \\
\hline \multirow[t]{2}{*}{$\begin{array}{l}\text { ATP, } \mathrm{CP} \rightarrow \mathrm{ADP}, \\
\text { creatine }\end{array}$} & 4.4 & instantly & 0.67 \\
\hline & [10] & [11] & [10] \\
\hline
\end{tabular}

Table 1: Availability of human energy resources. 
testosterone on human chess performance.

Bilalic and Chabris found no gender-specific chess excellence [17-19]. Since men and women may be differentiated mainly by their testosterone and not estradiol concentration (Table 2) [20], testosterone in physiological concentrations should therefore have no effect on mental chess excellence.

Hormone-values decrease from peak values by ca. $1 \%$ per year in women [21] and men [22].

When applying supra-pysiological androgens (for example nandrolone, glycogen in heart, liver and muscle remain unchanged [23] and competitive behaviour is increased in rats [24] and primates [25]. Moreover, this behavioural response was further increased when the androgens were combined with the stimulant amphetamine [26]. In addition Mazur [27] observed that winners of chess tournaments have higher testosterone concentrations than losers. Also, in certain circumstances, chess competitors show rises in testosteroneconcentration before their games, as if in preparation for the contests.

The positive role of androgens on brain cognition and aging are well known [28]. Androgen deficits cause significant loss of synapses in the hippocampus in rodent and nonhuman primates, increases amyloid deposition in human and rodent models and causes changes in neurotransmission in prefrontal cortex in rodent models [28]. Recent work suggests that these changes modify age-related cognitive loss, particularly to memory in men. However, testosterone treatment of healthy older men without cognitive deficits improved also cognitive properties, for example memory [29].

In the work of Davison [30] a comprehensive summary of testosterone effects on brain in men and women is found: neuroprotective properties, better performance in tasks of mathematical and spatial ability, superior performance on verbal fluency and memory tasks.

Is testosterone related to competition among women as it is among men? Is hormonal mediation of competition primarily a male characteristic [27]?

Possibly women have more sensitive testosterone mechanisms, so the smaller amount of the hormone found in women is sufficient to produce comparable effects.

Alternatively, estrogens or other hormones [31], that are more prevalent in women than in men may play an analogous role to that of testosterone. There exists some evidence to this suggestion. Azcoitia [32] observed that some of these effects of testosterone are blocked by aromatase inhibition and thus appear to be estrogen mediated. Aromatase is the enzyme responsible for the conversion of testosterone to estradiol. Janowsky [28] nreported that the conversion of testosterone to estradiol may play a special role in women in the preservation of memory in aging. In addition, estradiol enhances hippocampal dependent learning and memory in aged male and female mice [33].

\section{The downside of AAS}

Long-term use of supra-physiologic doses of AAS may cause irreversible cardiovascular toxicity, especially atherosclerotic effects and cardiomyopathy. In other organ systems, evidence of persistent toxicity is more modest. High concentrations of AAS, comparable to

\begin{tabular}{|l|c|c|}
\hline \multicolumn{1}{|c|}{ Specimen serum } & Testosterone $\mathbf{~ n m o l} / \mathbf{l}$ & Estradiol $\mathbf{~ p m o l / I}$ \\
\hline Male & $10-42$ & $37-110$ \\
\hline Female (day 1-10 menstrual cycle) & $0.7-2.6$ & $50-100$ \\
\hline
\end{tabular}

Table 2: Reference values of testosterone and estradiol in adult men and women. those likely sustained by many AAS abusers, produce apoptotic effects on various cell types, including neuronal cells-raising the specter of possibly irreversible neuropsychiatric toxicity [34].

Long-term AAS users showed no significant differences from nonusers on measures of response speed, sustained attention, and verbal memory. Concerning visuospatial memory, however, AAS users performed significantly more poorly than nonusers, and within the user group, visuospatial performance showed a significant negative correlation with total lifetime AAS dose. These were large effects on pattern recognition and Memory. Long-term AAS users underperformed nonusers by almost one standard deviation and performance on this test declined markedly with increasing lifetime AAS dose [35].

According to Grönbladh [36] the AAS analogue ND induced impairments of memory and also altered specific receptors in brain necessary for GH and IGF-I-activity. Furthermore, ND lowered IGF1 plasma concentrations. The findings regarding ND are worrying considering the common use of AAS among adolescents.

Conclusion: Long-term AAS use has no direct effect on energy for mental cognition and level of cognition. Concerning its effect on GH and IGF-I, visoaspatial memory and pattern recognition memory will be affected indirectly. AAS-users will perform mentally significantly worse than non-AAS-users.

Anabolic Agents (AA) ( $\beta_{2}$-adrenergic drugs, no steroids): $\beta_{2}$ Adrenergic drugs (clenbuterol for example) have anabolic effects, induce skeletal hypertrophy, and are found in brain after application. Clenbuterol has no effect on glycogen content in cells (absence of DNAincrease) [37].

Clenbuterol and other B2-agonists as anabolic drugs have no effect on GH- or thyroid and insulin-stimulation [38]. They rather act through increasing RNA and protein-synthesis. In summary, anabolic agents are able to increase skeletal muscle force production only when administered in supra-physiological doses or in combination with excessive training [2].

Clenbuterol improved performance in many young and aged rats and monkeys who performed poorly under control conditions. The effects of clenbuterol were not universal and depended on the cognitive status of the animal: the drug moderately improved only a subset of animals with working memory impairment [39].

In overdoses, Clenbuterol causes cardiac toxicity and type II myocardial infarction (MI) with associated symptoms such as agitation, palpitations, tachycardia, hypokalemia, and hyperglycemia [40].

Conclusion: In conclusion, men and women both have their specific hormonal endowments to participate sufficiently in competitive chess. Therapeutic treatment with testosterone or estradiol in agedependent decrease of gonadal hormones or in endocrine defects in the hypothalamus-hypophysis-gonads axis will improve cognitive performance as well as testosterone abuse by healthy older men and women. Longer use of supraphysiologic AAS concentrations, however results in severe clinical atherosclerotic effects, cardiomyopathy and apoptotic effects on neuronal cells. The latter side effects cause a significant decline of visuospatial performance and pattern recognition. The presented clinical data show that AAS use in a natural setting of gonadal hormonal endowment will impair chess performance.

\section{Energy for Chess Performance}

\section{Oxygen $\left[\mathrm{O}_{2}\right]$}


In general, the respiratory system does not limit maximal oxygen consumption in healthy subjects. Only in highly trained endurance athletes may blood oxygen saturation fall during heavy exercise [2]. Troubat [14] observed in his study a constant ventilation rate, so that a limitation of $\mathrm{O}_{2}$ during mental activity was excluded.

A limitation of the study of Troubat [14] remains because of the relative short time of the game (on the average 45 minutes for each player). In blitz-chess tournaments for example, the players have only 5 minutes for the complete game so that 10times as many conflict situations must be solved per time unit. In addition, Hollinsky [4] described, that HR measured during a chess tournament included peaks in excess of $220 / \mathrm{min}$ and a single maximum of $223 / \mathrm{min}$. Not surprisingly, at least to chess players, the peak HR is reached in the time pressure phase towards the end of the sixth hour of play $[4,41]$. It is also interesting to note that this player's adrenaline level reached almost eight times his normal rate, while Pfleger [41,42] observed increases of more than 3 fold. Hollinsky [4] noted that subjects experiencing HR in excess of 200/min and big increases in catecholamines were prone to make more simple mistakes on the chessboard because they were under extreme physical pressure.

Conclusion: A beneficial effect of drugs increasing availability of $\mathrm{O}_{2}$ for the chess player cannot be completely excluded, therefore, especially for chess-players with lung diseases, such as cystic fibrosis [43], or during chess plays carried out at high altitude [44].

\section{Glycogen}

In terms of rapidly available energy from glucose and glycogen, only a limited amount necessary for the completion of most of the competitions of chess players can be delivered $[14,45]$. The continuation of competition must then be carried out with energy derived from adipose tissue at a slower rate of availability. The high rate of mental performance is thus impaired and must be reduced. Especially attention and conflict control are involved [46,47].

Two natural methods are available to increase glycogen content in the body in order to increase the rapidly available energy.

Glycogen supercompensation is one of the adaptations induced by physical training. This happens when glycogen recovers to above its basal level after it decreases with acute exercise. Greater glycogen depletion induces greater glycogen supercompensation in skeletal muscle [48], suggesting muscle glycogen supercompensation is inducible in more active muscle for metabolic adaptation.

Exercise also increases neuronal activity and creates an energy demand in the brain $[49,50]$. During the recovery phase after exhaustive exercise, glycogen supercompensation in the brain occurs earlier (6h) than that of skeletal muscles and liver (24h). Brain glycogen levels decreased by $50-64 \%$ with exhaustive exercise, and supercompensated by $29-63 \%$ (whole brain $46 \%$, cortex $60 \%$, hippocampus $33 \%$, hypothalamus $29 \%$, cerebellum $63 \%$ and brainstem $49 \%$ ) at $6 \mathrm{~h}$ after exercise [51]. It must be assumed, that total body glucose energy resources (i.e. glycogen and free glucose) are interconnected by the central blood-glucose, which serves as a common regulating variable. Peters formulated his 'Selfish Brain Theory' regarding competition for glycogen energy resources throughout the whole body [52]. However, evolution would only support a cooperation rather than a competition of body organs for energy resources. In addition, restoration and supercompensation of brain glycogen after physical exercise is preferably accomplished if compared to muscle glycogen [51].

Additionally, 3 days of a hyper-carbohydrate diet seems to increases basal levels of muscle glycogen (also known as 'muscle glycogen loading'), and prolongs the time required to exercise exhaustion [53].

To potentiate glycogen synthesis under natural conditions, many athletes use supraphysiologic doses of anabolic androgenic steroids (AAS). However, Cunha [23] could show, that administration of superphysiological doses of ND had no effect on heart, liver and muscle glycogen of male rats.

Conclusion: In order to extend availability of rapid energy necessary for intensive chess playing, the chess player can increase his glycogen stores in brain, liver and muscle through regular aerobic and mental exercise as well as through carbohydrate-rich nutrition before the competition. Physical exercise also supercompensates glycogen of brain regions involved in mental exercise such as chess.

AAS have no effect on glycogen content of man.

\section{Stimulants}

Amphetamines: Amphetamines stimulate CNS, increase arousal, medullary respiratory center [2] and may mask fatigue by increase of free fatty acids [54]

It is hypothesised that these drugs may enhance all types of performance [55]. Tikhomirov [56] postulated, that the heuristic character of chess players can be explained by a complex interaction of emotional, motivational and cognitive processes and showed, that low arousal is associated with failure to solve the more difficult chess problems. Gobet [57] defines emotions as adaptive, quick and efficient alert systems. Emotions are important in acquiring and maintaining expertise.

In general, the data on acute effects show that amphetamines might improve cognitive performance in selected domains, that is, visuospatial perception, attention, and inhibition.

With the exception of the severe clinical side effects of amphetamine treatment, the clinical significance of these findings may be limited because cognitive functioning overwhelmingly falls within the normal range when compared against normative data.

Regarding long-term effects on cognitive performance and brain-imaging measures, statistically significant differences between methamphetamine users and control participants have been observed on a minority of measures [58]. Despite the lack of enhancement observed for most measures and most participants, participants nevertheless believed their performance was more enhanced by the active capsule than by placebo [59].

Another frequently reported deleterious effect associated with amphetamine abuse and dependence is cognitive impairment. Unlike the scant literature examining the effects of the drug on dental health, there is a burgeoning amount of information detailing the impact of methamphetamine on cognitive functioning. The dominant view is that illicit methamphetamine use causes a broad range of cognitive impairments [60]. In addition, Methamphetamine abuse is associated with multiple deleterious medical consequences, including paranoia mimicking full-blown psychosis [61] and hypertensive crisis leading to stroke [62].

Conclusion: Clinical data show, that acute amphetamine use has no effect and abuse will impair cognitive and chess performance.

Caffeine: Caffeine is the world's most widely consumed psychoactive substance, with 74 percent of Germans drinking several times daily [63]. The IOC classified caffeine as a doping agent in 1962, 
removed it from the list of banned substances in 1972, and currently has classified it as a restricted drug (positive at $>12 \mathrm{mg} / \mathrm{ml}$ in urine [2], in 2014 Included in WADA 2013 Monitoring Program and relevant for in-competition testing only.

Caffeine initially stimulates the CNS at the level of the cerebral cortex and medulla and only later stimulates the spinal cord (at higher doses). Its effects begin within $1 \mathrm{~h}$ and last for 3-4h. Caffeine significantly inhibited response blocking (attention lapses) in car drivers [64]. Caffeine elevates mood [65], increases alertness, reduces fatigue by lowering the threshold for exercise-induced $\beta$-endorphin release. An increase in $\beta$-endorphin is well known to enhance exercise performance through its ability to decrease pain perception and promote euphoria [66] and this not so much by sparing glycogen as usually is presumed $[2,67]$.

Normal caffeine consumption improves performance on tasks that require alertness, such as simulated driving tasks. The effect on more complex cognitive tasks is less clear, although there is evidence to suggest that high consumption is associated with better performance, especially in older people [68].

Elevated caffeine: Caffeine intakes of $\geq 1.4 \mathrm{mg} / \mathrm{kg}$ increased aortic stiffness, increased vascular resistance, decreased cerebral blood flow, and increased plasma epinephrine, lipids, and renin activity. The effects were typically greater in low users and in older subjects than in habitual caffeine consumers, and were exacerbated by concurrent hypertension. Caffeine increased plasma homocysteine levels in most experimental and population studies where it was evaluated. Epidemiological studies provided inconsistent association of caffeine with blood pressure in children. All but one of the 14 case-control studies with adults found a positive association of caffeine intake with increased risk of cardiotoxicity, including MI and sudden cardiac death with $12 \mathrm{~g}$ of pure anhydrous caffeine [69]. The cohort prospective studies, however, provided conflicting results, some finding an elevated risk of MI, increased blood pressure, or coronary death from consumption of 6-19 mg/kg/day, but other studies finding no association or an inverse association. Due to the heterogeneity of the data, a lowest-observable adverse effect level cannot be reliably determined for the effect of caffeine on cardiovascular parameters [70], although a research review regarding caffeine consumption concluded that among the healthy adult population a moderate daily caffeine intake of $\leq 400 \mathrm{mg}$ (on the average 4 pots of coffee) was not associated with any adverse effects [71].

Conclusion: Caffeine can be characterized as a stimulant for improving chess playing with respect to stimulation of cerebral cortex, increasing alertness, reducing pain perception and promote euphoria and mood.

\section{Diuresis}

In addition, caffeine may be characterized as a diuretic agent [72] (see diuretics).

Nicotine: Nicotine is a highly addictive substance, and cigarette smoking is a major cause of premature death among humans. Little is known about the neuropharmacology and sites of action of nicotine in the human brain.

Intravenous nicotine strongly activates in humans a distributed system of CNS regions implicated in the control and regulation of many of the behavioral states long attributed to nicotine use. The cingulate and several frontal lobe divisions, including the dorsolateral, orbital, and medial frontal, were among the most prominently activated regions
[73]. The frontal lobes-with their rich dopamine innervation-and the cingulated cortex-through its connections with many neocortical association, motor, and sensory regions-have been thought to be involved in the processing of such diverse cognitive states as working memory, attention, motivation, mood, and emotion [74].

Studies of the effects of nicotinic systems and/or nicotinic receptor stimulation in pathological disease states such as $\mathrm{AD}, \mathrm{PD}, \mathrm{ADHD}$ and schizophrenia show the potential for therapeutic utility of nicotinic drugs.

In contrast to studies in pathological states, studies of nicotine in normal-non-smokers and in normal elderly people tend to show deleterious effects [75], while nicotine had no effect in young persons. The effect of nicotine was dependent on baseline cognitive performance in young and old people with subjects with lower performance baseline benefiting from nicotine administration, while those with higher baseline performance performed worse after nicotine administration [75].

Although normal individuals are unlikely to show cognitive benefits after nicotinic stimulation except under extreme task conditions, individuals with a variety of disease states can benefit from nicotinic drugs. Attentional function/dysfunction may serve as an endophenotypic therapeutic target for nicotinic drug development [76].

Elevated nicotine: Though nicotine is one of the most toxic drugs of abuse, it has rarely led to fatalities. Sudden death can be caused by cardiovascular arrest, respiratory muscle paralysis and/or central respiratory failure. One fatal case was reported in the scientific literature [77]: A 42-year-old man was found dead by his wife. He was lying on the floor, next to a box containing many empty bottles of beer and vodka. Some labelled chemical bottles found at the scene contained various substances, including nicotine and brucine. Gross examination of the organs at autopsy revealed no specific findings. The toxicological examination failed to disclose any lethal toxic agents other than a high concentration of nicotine and its primary metabolite cotinine in femoral venous blood $(2.2 \mu \mathrm{g} / \mathrm{mL})$. Blood alcohol was determined to be $2.1 \mathrm{~g} / \mathrm{L}$ in femoral venous blood.

Conclusion: Chess players will not benefit from nicotine; on the contrary, at least elderly chess players might perform worse after nicotine administration.

\section{Narcotics}

As an example, cocaine will be discussed. The few studies on cocaine and exercise suggest that little to no performance gains are incurred from cocaine use. Moreover, the sense of euphoria may provide the illusion of better performance when, in actuality, performance was not improved or was impaired [55].

Cocaine abuse: Cocaine is a potent sympathomimetic drug that is associated with cardiotoxicity, including ventricular arrhythmia, systemic hypertension, acute MI and left ventricular hypertrophy. associated with a significant degree of cardiotoxicity, particularly coronary artery disease and ventricular hypertrophy, independent of cocaine concentration [78]. According to Degenhart [79] mortality is four to eight times higher among cocaine users than age and sex peers in the general population.

Cocaine has a negative impact on exercise endurance [80].

Conclusion: Beneficial effects of narcotics on chess excellence have not been observed. 


\section{Diuretics}

Diuretics would impair verification of substances in blood, which ameliorate chess performance. Caffeine shows diuretic properties (see chapter stimulants).

Peptides and proteohormones (EPO, GH, IGF-1, hCG, LH, Insulin, ACTH, Cortisol).

\section{Erythropoietin (Epo)}

Biologic effects: Epo is a naturally occurring glycoprotein that stimulates the proliferation and differentiation of erythroid progenitor cells [81].

Elevated concentrations: In elevated concentrations, Epo causes numerous, serious and often lethal side effects. Among these are for example in brain cerebral seizures, hematomas and haemorrhages [81] and stroke, hypertension, and cardiovascular risks vascular access, thrombosis risks [82]. In the clinical trial of Bennett [82] more than $90 \%$ of the participants reported adverse events. More than $10 \%$ discontinued the test, ca. $10 \%$ died during the test.

Conclusions: Epo has no effect on chess performance with the exception of chess plays at high altitudes and persons with lung diseases (see chapter $\mathrm{O}_{2}$ ).

\section{Growth hormone (GH)}

Metabolic effects: The metabolic effects of GH are listed here according to Vijayakumar [83] and Møller [84]:

- $\quad$ Stimulation of lipolysis in the adipose tissue resulting in an increased flux of free fatty acids (FFAs) into the circulation, muscle and liver.

- $\quad$ Stimulation of triglyceride uptake and subsequent storage.

- Antagonism of insulin action.

- Net anabolic effect on protein metabolism, may be due to fluid retention rather than muscle hypertrophy [85].

- Decrease of glucose oxidation (secondary to an increase in lipid oxidation) and suppression of muscle uptake of glucose.

- With abuse or therapeutic excess, GH shows diabetogenic actions with hyperinsulinemia, which may in the long term induce increased cardiovascular morbidity and mortality.

Furthermore, GH has a net anabolic effect on protein metabolism although the molecular mechanisms of its actions are not completely understood.

Athletic performance: $\mathrm{GH}$ is reportedly used to enhance athletic performance, although its safety and efficacy for this purpose are poorly understood. In a thorough meta-analysis of GH misuse in physical exercise, Liu [85] used 27 studies published in 44 articles to evaluate the efficacy of GH on athletic performance. The authors conclude: Claims that growth hormone enhances physical performance are not supported by the scientific literature. Although the limited available evidence suggests that growth hormone increases lean body mass, it may not improve strength; in addition, it may worsen exercise capacity and increase adverse effects.

The only study found in Medline with positive effects of GH on physical performance of recreational athletes was published in by Meinhardt [86].
Brain: One aspect of GH properties has not been considered in the discussion of human performance: the effects of GH on brain development (see also IGF).

The CNS is a target for GH indicating that the hormone crosses the blood-brain barrier.

GH-receptors are present in many regions of the brain [87]. Among these are in humans as well as in rats the choroid plexus, hippocampus, hypothalmus, and spinal cord.

GH (together with IGF-1) induced in the hypophysectomised rat cellular proliferation by a factor of more than 2 fold in the dentate gyrus (part of hippocampus, location of memory, short conflict control), hippocampus (memory, conflict control), corpus callosum (brain structure to connect actively both brain halves), striatum (regulation of voluntary motor activity), and the parietal (reception and processing of sensory information from the body) and piriform cortices (motivation, processing of information) [88].

The hippocampus, for example, is involved in GH dependent action on memory and cognitive function [89].

GH replacement therapy was found to improve the psychological capabilities in adult GH deficient (GHD) patients. Furthermore, beneficial effects of the hormone on certain functions, including memory, mental alertness, motivation, and working capacity, have been reported [89]. Falleti [90] evaluated 13 selected studies concerned with the effects of $\mathrm{GH}$ deficiency and $\mathrm{GH}$ replacement on cognitive performance in adults. In conclusion, this meta-analysis clearly demonstrated that initially present poor cognitive performance can be ameliorated with $\mathrm{GH}$ treatment. GH treatment also improved in man several cognition tests including Intelligence-, information-processinglearning-tests after traumatic brain injury [91].

GH in a natural setting, however, has another surprising effect. Mice lacking GH or GH receptor outlive their normal siblings and exhibit symptoms of delayed aging associated with improved insulin signalling and increased stress resistance. Recent studies of the role of the somatotropic axis, and specifically $\mathrm{GH}$, in the control of aging and longevity have added new evidence for the anti-aging and life-extending effects on GH resistance and GH deficiency in laboratory mice [92].

Elevated GH: Elevated GH concentrations, that occur for example in acromegaly, cause insulin resistance, leading to hyperglycemia, hyperinsulinemia, decreased glucose utilization, increased lipoplysis [93], central hypothyroidism [94], leukemia in cell culture [95]. Very disturbing data were represented by Takala [96]: two parallel studies provided strong evidence, that the administration of high doses of $\mathrm{GH}$ to critically ill adults receiving prolonged intensive care is associated with an increase in mortality; among the patients who survived, the duration of mechanical ventilation, intensive care, and hospitalization was prolonged by GH. GH therapy can have fatal consequences.

Persons with acromegaly, a syndrome that results when the anterior pituitary gland produces excess $\mathrm{GH}$, showed cognitive and neurophysiological impairment, characterized by moderate-to-severe memory impairment and decreased neural activity in specific brain areas [92].

Conclusions: The presented data do not indicate that GH might improve mental performance by means of energy availability.

When the effects of GH on brain performance in a natural setting are considered, a definite improvement of mental performance such as memory, learning, conflict control can be achieved by GH treatment of 
GH-deficient persons.

Chronic elevated GH will result in poorer cognitive performance.

\section{Insulin-like Growth Factor (IGF-I)}

IGF is a naturally occurring single chain polypeptide which has $48 \%$ structural homology with pro-Insulin. Insulin, GH and nutrition are the main regulators of hepatic IGF-production [97].

Glucose: IGF-I has an insulin-like activity, i.e. increased glucose disposal and suppressed insulin secretion [97].

Protein: Russel-Jones [98] could show, that IGF-I induced protein synthesis, but had no effect on protein degradation, while insulin reduced protein degradation with no effect on protein synthesis.

Brain: The concept that GH and IGF-1 are required for normal development of the mammalian body and, more recently the brain is supported by a vast experimental literature. Aleman [99] observed, that circulating IGF-I plays an ameliorating role in the age-related reduction of certain cognitive functions, specifically speed of information processing. IGF-1 and GH cross the blood-brain barrier and are bound by binding sites for example in the hippocampus, a brain structure important in the maintenance of cognitive functions such as learning and memory [100]. In recent years, much attention has focused on age-related decreases in serum GH and IGF- 1 as potential mechanisms that may influence cognitive function in the elderly. In rodents, GH and IGF increase cell genesis in several regions of the brains of GHIGF-I-deficient hypophysectomized rats [88] and long-term GH/ IGF-1 replacement improves learning and memory in aged rats. While the exact mechanism underlying these cognitive improvements is unknown, GH and IGF-1 replacement to aged animals increases neurogenesis, vascular density, glucose utilization, and alters NMDA receptor subunit composition in brain areas that are implicated in learning and memory [101]. Based on the available data, GH or IGF deficiency could contribute to the deterioration of cognitive functions observed in the elderly [100].

Many new functions of IGF-I in the brain and elsewhere are arising. This peptide forms an intricate functional network with other members of the family, in particular with insulin and GH, and interacts with many other neurotrophic signals. All brain cells are modulated by IGF-I, and its key role in health and disease is now firmly established. Whether IGF-I constitutes a master regulator of brain homeostasis is open to discussion, but current knowledge of its functions in this organ support this possibility [102].

Elevated IGF-I: In elevated concentrations, IGF-I is both an anabolic and mitogenic agent for skeletal muscle or muscle lineage cells [103]. High concentrations of IGF-I were also associated with an increased risk of prostate cancer and premenopausal breast cancer [104]. Results from recent studies provide evidence of cognitive and neurophysiological impairment, characterized by moderate-to-severe memory impairment and decreased neural activity in specific brain areas. High levels of IGF-I in acromegaly patients could be the basis for these findings [92].

Conclusion: In conclusion, IGF-I improves in natural concentrations energy availability as well as cognitive function in man. In chronic elevated concentrations IGF-I causes moderate to severe cognitive impairment.

Luteotropic hormone (prolactin, LH) and human choriogonadotropin (HCG)
Gonads: Parenteral administration of LH or HCG stimulates the production of testosterone in the testes of males and progesterone and estradiol in females and these gonadotropins can therefore be used by athletes to enhance muscle strength [105]. However, they are more expensive and less efficient than testosterone and anabolic steroids. Therefore their main use is probably to stimulate gonadal testosterone production during and after self-administration of testosterone or anabolic steroids. A positive effect of HCG on muscle strength has not been demonstrated in women and elevated concentrations of HCG in females are often caused by pregnancy. The use of gonadotropins is therefore prohibited only in males but not in females [106].

Brain: One of the processes associated with age-related reduction of testosterone concentration in men [107] and estradiol in women [108] is the cognitive decline in men [109] and women [108].

Declining levels of estrogen in women [108] result in increases in gonadotropins such as LH and HCG through loss of feedback inhibition. These processes are considered to be crucial for the development of agerelated cognitive impairments and even the progression of $\mathrm{AD}$ [110]. The question arises, whether the loss of estrogens or the high levels of gondadotropins are the cause for the cognition decline.

HCG and LH are capable to cross the blood-brain barrier and can be detected in cerebrospinal fluid and in several parts of the brain. Receptors for gonadotropins are found in the hippocampus [111,112], a key brain area responsible for cognition affected by aging and which is severely deteriorated in $\mathrm{AD}$ [113].

Bryan [110] could indeed show, that restoration of cognitive impairments is possible in laboratory animals (mice) by downregulation of gonadotropins without use of estrogens. Similar results were published by Casadesus [114], which showed that transgenic mice with overexpressed LH showed decreased mental performance. These findings indicate that increased luteinizing hormone levels, in the presence of functional receptors may be responsible for cognitive decline after menopause.

Berry [115] tested female rats for spatial memory of rats after treatment with HCG and observed a decline of memory performance.

Elevated LH: Elevated LH is usually associated with hypogonadism, low testosterone and normal FSH blood levels. hCG administration rises plasma testosterone and normalizes the clinical condition [116]. Cognitive impairement in central hypogonadism in male is usually associated with pituitary tumors [117].

Conclusions: Gonadotropins HCG and LH show two-edged effects on brain performance, i.e. a decline by the gonadotropins and a rise caused by induced testosterone.

\section{Insulin}

Almost all cell types are responsive to insulin. However, brain, liver, muscle, and adipose tissue are the most sensitive to the hormone, rendering it the most important anabolic hormone identified to date. The major effects of insulin are manifold, but may be categorized for four main purposes to enable synthesis of carbohydrates, fat and proteins and prevent neurodegeneration $[118,119]$ :

Glucose: Insulin increases glucose transport across the cell membrane in adipose tissue and muscle. It accelerates glycolysis in muscle and adipose tissue depending on phosphorylation of glucose. Insulin increases of glycogen synthesis in adipose tissue, muscle, and liver. It decreases glycogen breakdown in muscle and liver and rate of glycogenolysis and gluconeogenesis in liver. 
Lipids: Decrease of rate of lipolysis in adipose tissue resulting in a decrease of blood fatty acid concentrations. Insulin accelerates synthesis of fatty acids and neutral fat molecules, and increases the rate of cholesterol synthesis in liver.

Protein: Increase of transport of some amino acids into tissues and rate of protein synthesis in muscle, adipose tissue, liver, and other tissues. Insulin decreases rate of protein degradation in muscle and urea formation.

Brain: In brain insulin regulates both peripheral and central glucose metabolism and is therefore associated with neuroprotective properties. Insulin signalling in brain is positively associated with learning, memory, and negatively with age related neurodegenerative diseases. Insulin resistance in brain has also been associated with diabetes and aging in CNS with AD considered to be the "brain-type diabetes" [119].

Insulin application: Insulin is available for therapeutic therapy of insulin deficiency in numerous formulations. Its use by the intramuscular or subcutaneous route however is often associated with non-adequate concentrations in blood.

The development of technologies in the last decade has brought non-injectable insulin delivery to reality. A rigorous research effort has been undertaken worldwide to replace the authentic subcutaneous route by a more accurate and non-invasive route. Peroral, nasal, and pulmonary administration has demonstrated good potential for treatment of diabetes. In addition, transmucosal, buccal, ocular, rectal, and vaginal routes of insulin have also shown to decrease serum glucose concentrations. The transdermal route using various technologies also exhibits success in delivering insulin [120]. These new application methods seem to favour non-authorized application of insulin, since a hypoglycaemia will not rise as easily as with insulin injection; additionally, insulin determination in blood and urine will be complicated because insulin may not be metabolized by the circulation route.

Elevated insulin: The administration of exogenous insulin by various routes increases muscle glycogen before and after the recovery stages of strenuous exercise. This may improve mental and physical performance with the rapidly available energy and may assist in recovery of mental and physical exercise.

Beside diabetic persons, hypoglycaemia is a regular occurrence in people, who inject insulin to improve athletic performance and may be associated with cognitive and affective outcomes [121]. Mood changes by changes by fluctuations in glycemic control together with depressive and anxiety states, sometimes also with euphoria. The most serious consequences of hypoglycaemia is a decrease of brain glycogen, together with hypoglycaemic convulsions, neuro-glycopenic coma [122] and even death due to brain failure [123].

Conclusions: Insulin is responsible for the transport of glucose through cell membranes to glycogen synthesis, and then to glycogenolysis and glucose-1-phosphate in all organs of the human body which contain glycogen. Insulin is therefore essential for the function of energy metabolism depending on glucose. It therefore has neuroprotective properties and insulin is signalling for a positive effect on learning and memory and a negative effect on age related neurodegenerative diseases. Insulin therefore would definitely improve conflict control during chess playing.

Adreno-Corticotrophic Hormone $\quad$ (ACTH) and
corticosteroids (cortisol)

Adrenocorticotrophic hormone (ACTH), also known as corticotrophin, is a proteohormone and secreted by the hypophysis. It is produced on the basis of an diurnal rhythm with high values in the morning and low values around midnight and often by mental and physical stress via the hypothalamic-hypophysis-axis. Its principal effects are increased production and release of corticosteroids. The principal steroid hormone produced by the adrenal gland is cortisol, which also is present in blood following the diurnal rhythm of ACTH.

ACTH has been used therapeutically in some childhood seizures. During longer ACTH-treatment, brain (rat) develops more dendrite branches [124]. Some additional effects of ACTH have been described on neurotransmitters dopamine, norepinephrine, serotonon and GABA (gamma-aminobutyric acid) [125]. Therapeutic cortisol or analogues are used for diagnosis of Morbus Cushing or Addison and for control of inflammation diseases.

Conclusions: The benefits and disadvantages of ACTH on performance enhancement in physical and mental strain therefore will be mainly derived from cortisol and analogues.

Glucocorticoids (Cortisol and Analogues)

\section{Glucose}

In the fasting state and in physical or mental stress, cortisol accelerates gluconeo-genesis i.e. synthesis of glucose from glucogenic amino acids [126] in brain, liver, and muscle-cells and stimulates antiinflammatory reactions. In addition, cortisol induces glygogenolysis in liver, brain and muscle [127] by adrenalin.

\section{Brain}

Normally, Cortisol concentrations do not change with ageing [128]. According to Stawski [129], cognitive function in his study with 1500 humans ranging between 33 and 84 years was associated with sound cortisol profiles, including a steeper diurnal cortisol rhythm, higher morning and lower evening levels.

In healthy older men, higher plasma cortisol levels were negatively associated with ageing-related overall cognitive function (memory and processing speed) but not ageing-related brain atrophy [130]. Porter [131], observed, that effects of corticoids on cognitive brain function do not occur only after disrupting the diurnal rhythm of cortisol by a high dose of cortisol (10 fold elevation). In addition, Lupien [132] showed that subjects presenting a decrease in cortisol levels with years performed as well as young healthy subjects with regard to cognitive performance. Thus, impaired cognitive performance was associated with recent evidence of hypothalamic-pituitary-adrenal dysregulation and elevated basal cortisol levels.

\section{Elevated cortisol}

In general, it is reported that corticosteroids impair selective attention, that is, the ability to discriminate relevant from irrelevant information, which is in accordance with electrophysiological findings that acute administration of cortisol to human subjects reduces the average evoked potential response to relevant but not to irrelevant stimuli [133]. These findings are also consistent with studies showing that glucocorticoids can impair and hippocampal long term function [134].

The role of the hippocampal formation in human learning and memory is now well established [135]. More importantly, studies report that the hippocampus is essential for the long term memory [136], which is necessary conscious or voluntary recollection of stored information. 
In addition to cognitive impairment, elevated cortisol presents numerous side effects such as [137]:

- $\quad$ Skin: skin atrophy, disturbed wound healing

- $\quad$ Skeleton, muscle: osteoporosis, muscle atrophy, myopathy

- $\quad$ Eye: cataract, glaucoma

- CNS: mood swings, euphoria, depression, suicide attempts, mania, hallucinations, and delusions

- $\quad$ Endocrine systems: diabetes mellitus, adrenal insufficiency

- Cardiovascular system: hypertension, dyslipidemia, a reduced fibrinolytic potential

- Gastrointestinal system: peptic ulcers, upper gastrointestinal bleeding, pancreatitis, oral candidiasis

- Immune system: increase of all kinds of infections, inhibition of the inflammatory and specific immune systems, reactivation of cytomegalovirus

- $\quad$ skin atrophy, disturbed wound healing

- $\quad$ diabetes mellitus

- $\quad$ adrenal insufficiency.

\section{Conclusions}

While cortisol-induced additional glucose would certainly delay onset of fatigue in physical and mental strain, some special effects of corticosteroids on brain will impair chess performance. It must be realized from these data that significant elevations of cortisol for longer periods cause hippocampal dysfunction and cognitive impairments in long time memory, which would directly affect the competitive chess player. If a certain threshold of hippocampal dysfunction is reached, it can be postulated that neuron loss will occur that will be related to more severe and irreversible cognitive deficits (Table 3).

\section{Drugs for improvement of mental performance in chess}

Mental performance consists of several cognitive functions which are distinct but very coherent. Memory is the ability to remember learned materials or events. Attention is the ability to focus while ignoring distractions. Creativity is the ability, to establish new relationships and new non-obvious meanings. Intelligence is the problem solving ability [138].

An expert chess performance is based on a specific domain expertise consisting of above described properties of mental performance. The expertise is obtained by

- At least ten years of training

- Beginning as early as possible in life

- $\quad$ Spending at least 10000 hours training time in those ten years

- $\quad$ Memorising up to 10000 chess positions at master level and 300000 at grand-master level $[139,140]$.

Can drugs really accelerate the process of obtaining chess expertise? Can a grandmaster participating in a tournament really improve his actual chess expertise gained in 20 years of continuous training and participating in thousands of competitive chess games by taking drugs before the actual tournament? Should a chess player take cognitive drugs from the beginning of chess training (in the ideal case already before beginning of elementary school) in order to become a superior chess master many years later?

\section{Neurological basis of mental expertise in chess}

Expertise in a specific mental domain such as chess enables a chess player to perform as an expert is an intrinsically cognitive domain which taps many cognitive processes that are typically associated with intelligence, such as mental speed, spatial abilities, working memory, reasoning and perception [141,142], motivation [143], attention [144], recognition [145] and creativity [138].

\section{Summary of desired effects and side effects of drugs for CE}

Lanni summarized mental performance with memory, attention, creativity and intelligence [138]. These cognitive functions also are also essential parts of chess expertise. Lanni [138] assigns in his review diverse CE drugs to attention, memory and creativity (Table 4) in diverse clinical settings, but not one to intelligence. Intelligence is a difficult term in Biology and Psychology. For example, the intelligence quotient (IQ) of experienced chess players is not significantly different from that of the general population [146,147]. Obviously, a long and intensive chess training of experienced chess players could not enhance intelligence as measured by IQ-tests. For this reason Grabner [140] defined for chess players a domain specific intelligence for very good chess players. In consequence a similar mental expertise (specialized domain specific intelligence) will be found also as musical intelligence, logical-mathematical intelligence, spatial and visual intelligence, linguistic intelligence, physical-kinaesthetic intelligence, interpersonal or "social" intelligence, intrapersonal or intuitive intelligence, balanced intelligence and so on [148].

CE drugs were originally developed to treat cognitive disabilities such as narcolepsy, dementia, AD, PD, schizophrenia or ADHD and depression [16].

Increasingly, however, healthy individuals use CE drugs such as moldafinil and methylphenidate to improve cognitive functions including attention and working memory $[16,149]$, On university campuses around the world, students are striking deals to buy and sell prescription drugs such as Adderall and Ritalin - not to get high, but to get higher grades, to provide an edge over their fellow students or to increase in some measurable way their capacity for learning, as if traditional use of substances to enhance cognitive and psychomotor performance such as caffeine and nicotine seem insufficient to counteract the consequences of our 24 hour society. For example, in a study of the University at Mainz, Germany, the estimated 12-month prevalence of CE drug use among the students was 20\%. Prevalence varied by sex (male $23.7 \%$, female $17.0 \%$ ), field of study (highest in students studying sports-related fields, 25.4\%), and semester (first semester 24.3\%, beyond first semester 16.7\%) [150].

A thorough search of the scientific literature on CE drugs, however, creates no optimism on efficacy of CE drugs at the moment. When rigorous standards for clinical studies are applied (placebo controlled, double blind, magnitude of effects and side effects), only a few studies remain for evaluation of efficacy of CE-drugs.

Despite wide-spread optimism, available pharmacological agents do not seem to provide substantial cognitive-enhancing effects [151].

There exists till now no robust evidence that these agents have a particular and appreciable advantage in terms of improving cognitive functioning. Even though studies find statistically significant treatment effects on cognition, these gains are poor or almost impalpable on a clinical and functional level. Furthermore, there exists no information on the long-term effects on cognition. In addition, the studies show 


\begin{tabular}{|c|c|c|c|c|}
\hline \multirow[t]{2}{*}{ Hormone } & \multirow{2}{*}{$\begin{array}{l}\text { Glucose/ } \\
\text { Glycogen }\end{array}$} & \multicolumn{2}{|c|}{ Mental performance } & \multirow{2}{*}{$\begin{array}{l}\text { General side effects } \\
\text { Elevated concentration }\end{array}$} \\
\hline & & $\begin{array}{l}\text { Normal } \\
\text { concentration }\end{array}$ & $\begin{array}{l}\text { Elevated } \\
\text { concentration }\end{array}$ & \\
\hline Epo & No effect & No effect ${ }^{1}$ & No effect ${ }^{1}$ & $\begin{array}{l}\text { Cerebral seizures, hematomas and haemorrhages, stroke, hypertension, cardiovascular risks vascular access, } \\
\text { thrombosis risks, occurrence of death }\end{array}$ \\
\hline $\mathrm{GH}$ & No effect & Positive effect & Negative effect & $\begin{array}{l}\text { Acromegaly, insulin resistance, hyperglycemia, hyperinsulinemia, hypertension, decreased glucose utilization, } \\
\text { increased lipoplysis, leukemia, hypothyroidism, increased mortality in critically ill }\end{array}$ \\
\hline IGF-I & $\begin{array}{l}\text { Positive } \\
\text { effect }\end{array}$ & Positive effect & Negative effect & Muscle hypertrophy, muscle mitogenic, increase of premenopausal breast and prostate cancer \\
\hline LH/hCG & No effect & No effect & Negative effect & Hypogonadism \\
\hline Insulin & $\begin{array}{l}\text { Positive } \\
\text { effect }\end{array}$ & Positive effect & Negative effect & $\begin{array}{l}\text { Hypoglycaemia, sometimes with severe brain dysfunction and seldom death, mood changes, depression, } \\
\text { anxiety }\end{array}$ \\
\hline $\begin{array}{l}\text { ACTH } \\
\text { (cortisol) }\end{array}$ & $\begin{array}{l}\text { Positive } \\
\text { effect }\end{array}$ & No effect & Negative effect & $\begin{array}{l}\text { Decline mental performance, diseases of skin, skeleton, muscle, eyes, CNS, endocrine systems, } \\
\text { cardiovascular system, gastrointestinal system, immune system }\end{array}$ \\
\hline AAS & No effect & Positive effect & Negative effect & Cardiovascular, arteriosclerosis, cardiomyopathy, decrease of visiosapatiol memory, pattern recognition \\
\hline $\begin{array}{l}\text { Anabolic } \\
\text { agents } \\
\text { Clenbuterol }\end{array}$ & No effect & - & $\begin{array}{l}\text { Positive } \\
\text { effects for low } \\
\text { baseline }\end{array}$ & $\begin{array}{l}\text { Cardiac toxicity and type II MI with associated symptoms such as agitation, palpitations, tachycardia, } \\
\text { hypokalemia, and hyperglycemia }\end{array}$ \\
\hline $\begin{array}{l}\text { Ampheta- } \\
\text { mines }\end{array}$ & No effect & - & $\begin{array}{l}\text { Positive } \\
\text { with limited } \\
\text { significance }\end{array}$ & $\begin{array}{l}\text { Cognitive impairments, multiple deleterious medical consequences, including paranoia mimicking full-blown } \\
\text { psychosis, hypertensive crisis leading to stroke }\end{array}$ \\
\hline Caffeine & No effect & - & Positive effect & $\begin{array}{l}\text { Aortic stiffness, increased vascular resistance, decreased cerebral blood flow, increased plasma epinephrine, } \\
\text { lipids, and renin. increased risk of cardiotoxicity, including } \mathrm{Ml} \text { and sudden cardiac death }\end{array}$ \\
\hline Nicotine & & - & $\begin{array}{l}\text { No effect } \\
\text { In elderly } \\
\text { negative effect } \\
\text { in normal }\end{array}$ & $\begin{array}{l}\text { Sudden death can be caused by cardiovascular arrest, respiratory muscle paralysis and/or central respiratory } \\
\text { failure. }\end{array}$ \\
\hline $\begin{array}{l}\text { Narcotics } \\
\text { (cocaine) }\end{array}$ & No effect & - & Negative effect & $\begin{array}{l}\text { Cardiotoxicity, ventricular arrhythmia, systemic hypertension, acute } \mathrm{MI} \text {, ventricular hypertrophy. Coronary artery } \\
\text { disease, mortality is four eight times higher than in the general population. }\end{array}$ \\
\hline CE-drugs & & - & $\begin{array}{l}\text { Positive for } \\
\text { low base line } \\
\text { of cognition, } \\
\text { with limited } \\
\text { significance } \\
\text { for normal } \\
\text { cognition }\end{array}$ & Many deleterious side effects, including toxicity with danger of life and physical or psychological dependence \\
\hline
\end{tabular}

Table 3: Summary of effects of AAS, AS, nicotine, narcotics and hormones on chess performance.

that there are little differences in terms of cognitive-enhancement even compared to placebo: one study [152] even showed a better cognitive improvement in the placebo group. In addition, many of the CE drugs are most effective only on patients characterized by the lowest baseline of cognitive performance [153-157], while even impairing performance of patients with high baseline cognitive function [154,158-161].

For the time being, available pharmacological agents seem to provide modest (if any) appreciable cognitive benefits to patients suffering cognitive deficits. Furthermore, there seems to be rather scarce evidence of any direct specific cognitive-enhancing effect of drugs on normal persons, such as chess players.

\section{Alternatives for use of CE-Drugs}

In respect to the efficacy of $\mathrm{CE}$ drugs, it seems reasonable to hypothesize that more resources - both financial and human - might be better off invested in complementary treatment schemes (e.g., cognitive remediation, vocational training, metacognitive training) that do provide important, direct, and meaningful improvements for patients and normal persons.

Indeed, a number of approaches to remediating cognition in schizophrenia have been developed and studied in the last 15 years and this literature has been reviewed in six meta-analytic studies. With the exception of one [162], all have found moderate to large effect sizes [163-167] effect sizes far greater than those observed for any drug treatment. Also, these remediation effects are durable up to at least 6 months after the interventions are withdrawn [168]. Finally, and most importantly, these neuropsychological gains translate to improvements in real-world activities [169-171]. Similarily, cognitive remediation programmes address prominent, complementary functional domains such as social cognition - and studies have furthermore observed beneficial effects on functional outcome measures in patient's posttreatment $[172,173]$. Future studies should furthermore address the combination of cognitive and pharmacological treatment schemes that provide the widest and more enduring benefits for the patients.

\section{The downside of drugs for $\mathrm{CE}$}

Many of the CE drugs may be accompanied by deleterious side effects, including toxicity and physical or psychological dependence. These risks may be exacerbated by long-term use, which may be necessary to achieve or maintain the desired enhancement effect.

Like all drugs, those used with the aim of enhancing cognition 
can have side effects via body systems other than the brain. Thus, both Acetylchilinesterase-Inhibitors (AchEIs) and methylphenidate frequently cause gastrointestinal upset or nausea, sometimes leading patients to discontinue medication altogether. Adderall, for example, a combination medication (amphetamine and dextroamphetamine) is widely used in the USA to treat ADHD as part of a total treatment plan, including psychological, social, and other treatments. It may help to increase the ability to pay attention, concentrate, stay focused, and stop fidgeting. Adderall has numerous side effects ranging in the alphabet from appetite loss to sudden death.

These effects have the potential to offset any positive effects of the drug on overall performance, and also need to be borne in mind by anyone contemplating use of such drugs for non-medicinal purposes. More important from a cognitive neuroscience perspective is the ability of some drugs to impair certain aspects of cognition while simultaneously enhancing others in the same individual.

Thus, rivastigmine in healthy elderly subjects can improve learning on a motor task and making associations between symbols and digits, but can at the same time impair verbal and visual episodic memory [174]. Similarily, the dopamine agonist bromocriptine can enhance spatial Working Memory (WM) while simultaneously impairing probabilistic reversal learning in young participants [175]. This finding echoes results in patients with PD: dopaminergic medication improves their performance on WM and task-set switching tasks, but degrades reversal learning [176]. It has been hypothesized that such opposing effects are due to 'overdosing' of ventral striatal areas involved in the latter, but replenishment of dopamine in dorsal striatal areas required for the former [177]. Thus, doses of dopaminergic medication sufficient to ameliorate motor function and some aspects of cognition in PD have the potential to worsen others.

Indeed, this conclusion might well be applicable to recent reports that some PD patients on dopaminergic agonists developed impulsive behaviors such as gambling, compulsive shopping and hypersexuality $[178,179]$. It has been reported that such behavior in PD is often associated with the presence of dyskinesia, involuntary movements due to excessive dopaminergic stimulation [180], consistent with the notion that such impulse control disorders might indeed be associated with 'overdosing' of some basal ganglia regions. Importantly, reducing the dose of dopaminergic drugs often leads to reductions in impulsivity. These findings show that dopamine agonists in PD can have a spectrum of effects, both beneficial and harmful, on cognition and behavior.

\section{Effects of Genotype on Drug Response}

Genetic predictors of individual variability in response to treatments aimed at improving cognitive function would clearly be beneficial in effective targeting of therapeutic strategies. Several studies have suggested a role for polymorphisms in the catechol-Omethyltransferase (COMT) enzyme-coding region on chromosone 22 in WM. COMT degrades catecholamines, including dopamine, at the synapse. Polymorphisms of the COMT gene seem to be associated with variability in human WM performance and associated brain activity, presumed to be via its putative influence on cortical dopamine levels [181].

For the AChEIs, extensive metabolizers of drugs as defined by gene variations in cytochrome P450 (a family of degradative enzymes) might show greater response to donepezil and rivastigmine [182,183].

\section{Conclusion}

It is fair to say that we are still in the first generations of studies to examine the potential for $\mathrm{CE}$ in humans. In both healthy individuals and many patient groups, the overall effects of drugs generally seem to be modest. However, there is evidence that there might be more significant effects in subgroups, such as those whose baseline performance is poorest or individuals with a particular genotype.

Chess players, especially those who compete competitively are usually characterized as persons with a cognitive performance in their specific domain ranging far away from baseline cognition, where $\mathrm{CE}$ drugs are sometimes effective, mostly without clinical significance. It is not conceivable, that the $\mathrm{CE}$ dugs of today will enhance chess expertise.

In addition, the described side effects of CE drugs have the potential to offset any positive, if here is one, effects of the drug on overall performance, and also need to be borne in mind by anyone contemplating use of such drugs for non-medicinal purposes.

\begin{tabular}{|c|c|c|c|c|}
\hline Class & Drug & $\begin{array}{c}\text { Cognitive } \\
\text { domain }\end{array}$ & Approved use & Off label or investigational use \\
\hline $\begin{array}{l}\text { Cholinergic } \\
\text { agents }\end{array}$ & $\begin{array}{l}\text { Donezepil, rivastigmine, } \\
\text { galantamine }\end{array}$ & $\begin{array}{l}\text { Memory, } \\
\text { attention }\end{array}$ & Symptomatic treatment of $A D$ & $\begin{array}{c}\text { Vascular dementia, dementia associated with } \\
\text { PD, with memantine to improve attention/ } \\
\text { executive function in AD patients, Down } \\
\text { patients, may improve core ADHD symptoms, } \\
\text { used in militare personnel to treat psychic } \\
\text { trauma. }\end{array}$ \\
\hline $\begin{array}{l}\text { Nicotinic } \\
\text { agents }\end{array}$ & $\begin{array}{c}\text { Nicotinic alpha-7 receptor agonists (MEM } \\
63908, \text { MEM 3454) Memory - MEM 63908 } \\
\text { for AD; MEM } 3454 \text { for schizophrenia and/ } \\
\text { or AD } \\
\text { Alpha4beta2 nicotine, } \\
\text { Acetylcholine receptor partial } \\
\text { agonist (TC-1734) }\end{array}$ & Memory & $\begin{array}{l}\text { None } \\
\text { None }\end{array}$ & $\begin{array}{l}\text { MEM } 63908 \text { for AD; MEM } 3454 \text { for } \\
\text { schizophrenia and/or AD } \\
\text { AD, cognitive deficits in schizophrenia and other } \\
\text { conditions marked by cognitive impairment such } \\
\text { as ADHD; AAMI, and MCl }\end{array}$ \\
\hline \multirow[t]{2}{*}{$\begin{array}{l}\text { Glutamatergic } \\
\text { agents }\end{array}$} & Ampakine & $\begin{array}{l}\text { Memory, } \\
\text { attention }\end{array}$ & $\begin{array}{c}\text { Treatment of patients with moderate to } \\
\text { severe } A D\end{array}$ & CX516 for cognitive deficits in schizophrenia \\
\hline & Memantine & $\begin{array}{l}\text { Memory, } \\
\text { attention }\end{array}$ & & $\begin{array}{l}\text { Chronic headache and migraine prevention; } \\
\text { treatment of ADHD in paediatrics patients; in } \\
\text { association with rivastigmine to improve the } \\
\text { attention/executive function in AD patients }\end{array}$ \\
\hline
\end{tabular}




\begin{tabular}{|c|c|c|c|c|}
\hline \multirow[t]{4}{*}{$\begin{array}{l}\text { Agents once } \\
\text { supposed to } \\
\text { act through } \\
\text { glutama-tergic } \\
\text { mechanisms }\end{array}$} & Piracetam & $\begin{array}{l}\text { Memory, } \\
\text { attention }\end{array}$ & $\begin{array}{l}\text { Used in attention and memory disorders } \\
\text { of degenerative or vascular origin in the } \\
\text { Iderly,treatment for alcohol withdrawal. }\end{array}$ & Potentially used for $\mathrm{AD}$ and $\mathrm{MCl}$ \\
\hline & Aniracetam & & $\begin{array}{c}\text { Used in attention and memory disorders } \\
\text { of degenerative or vascular origin in the } \\
\text { elderly }\end{array}$ & $\begin{array}{l}\text { Potential treatment for cognitive impairment } \\
\text { associated with } \mathrm{AD} \text { and schizophrenia, } \\
\text { depression, slowing the progression and } \\
\text { potentially enhancing recovery from PD. }\end{array}$ \\
\hline & Oxiracetam & & 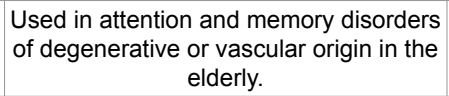 & Potentially used for $\mathrm{AD}$ and $\mathrm{MCl}$ \\
\hline & Nefiracetam & & & $\begin{array}{l}\text { Although it is not conclusively shown to be } \\
\text { effective as an } A D \text { medication, it could possibly } \\
\text { be useful as an analgesic }\end{array}$ \\
\hline \multirow[t]{3}{*}{$\begin{array}{l}\text { Stimulants and } \\
\text { agents active on } \\
\text { catecholamines }\end{array}$} & Methyphenidate & $\begin{array}{l}\text { Memory, } \\
\text { attention }\end{array}$ & Treatment for ADHD and narcolepsy & Used to improve attention in students \\
\hline & Moldafinil & & $\begin{array}{c}\text { Narcolepsy; approved for use in the } \\
\text { US and certain European countries in } \\
\text { patients with excessive } \\
\text { sleepiness associated with narcolepsy, } \\
\text { obstructive sleep } \\
\text { apnoea/hypopnoea syndrome or shift- } \\
\text { work sleep disorder; } \\
\text { in some countries, it is also approved } \\
\text { for idiopathic hypersomnia. }\end{array}$ & $\begin{array}{l}\text { Used to suppress the need for sleep, to contrast } \\
\text { general fatigue unrelated to lack of sleep (see } \\
\text { for } \\
\text { example the administration to healthy military } \\
\text { personnel), to treat ADHD, and as an adjunct to } \\
\text { antidepressants (Particularly in individuals with } \\
\text { significant residual fatigue). }\end{array}$ \\
\hline & Atomoxetine & & $\begin{array}{l}\text { Treatment for paediatric and adult } \\
\text { ADHD }\end{array}$ & $\begin{array}{c}\text { Quite diffused in healthy students to enhance } \\
\text { attention }\end{array}$ \\
\hline \multirow[t]{3}{*}{$\begin{array}{l}\text { Agents that act } \\
\text { on cerebral } \\
\text { circulation/ } \\
\text { metabolism }\end{array}$} & Nimomidine & Memory & $\begin{array}{l}\text { Approved for oral } \\
\text { administration to improve } \\
\text { neurological outcome after } \\
\text { subarachnoid hemorrhage. }\end{array}$ & \\
\hline & Idebenone & & & Treatment for Friedreich's ataxia and stroke \\
\hline & Hydergine, nicergoline & & $\begin{array}{l}\text { Used in brain disorders of } \\
\text { vascular origin in the elderly }\end{array}$ & $\begin{array}{l}\text { Used to combat decreased mental function as a } \\
\text { result of senility or multiple small strokes }\end{array}$ \\
\hline $\begin{array}{l}\text { Antidepressant } \\
\text { (NASSA) }\end{array}$ & Mirtazapine & Attention & $\begin{array}{l}\text { Used for the treatment of } \\
\text { moderate to severe depression } \\
\text { or as an add on medication to } \\
\text { enhance the effectiveness of } \\
\text { agents such as duloxetine and } \\
\text { venlafaxine in severe and } \\
\text { treatment-resistant } \\
\text { depression. }\end{array}$ & $\begin{array}{l}\text { Used to contrast panic disorder, generalized } \\
\text { anxiety disorder, obsessive-compulsive } \\
\text { disorder, } \\
\text { post-traumatic stress disorder }\end{array}$ \\
\hline $\begin{array}{l}\text { Miscellaneous } \\
\text { others }\end{array}$ & $\begin{array}{l}\text { Acetyl-I-carnitine, lecithin, } \\
\text { gingko biloba, ginseng, } \\
\text { antioxidants }\end{array}$ & $\begin{array}{l}\text { Memory, } \\
\text { attention }\end{array}$ & $\begin{array}{c}\text { Some of them may have approved uses } \\
\text { in EU countries for various conditions. } \\
\text { Widely used in integrator formulations } \\
\text { to } \\
\text { improve mental performance }\end{array}$ & $\begin{array}{l}\text { Supplementation has been shown to be } \\
\text { neuroprotective in cerebral ischemia, peripheral } \\
\text { nerve injury and to reverse symptoms } \\
\text { associated with mental decline in the elderly. } \\
\text { Studied in Alzheimer's disease and other } \\
\text { dementias. Can improve attention in healthy } \\
\text { individuals and improve cognitive performance } \\
\text { in various neurodegenerative disorders. }\end{array}$ \\
\hline $\begin{array}{l}\text { Cannabis } \\
\text { derivatives }\end{array}$ & Marijuana & Creativity & None & $\begin{array}{l}\text { Used to reduce chronic pain, to treat pain } \\
\text { caused by rheumatoid arthritis, to relieve } \\
\text { spasticity in multiple sclerosis, to treat epilepsy } \\
\text { owing to its serotonin-mediated anticonvulsant } \\
\text { action. }\end{array}$ \\
\hline Psychomimetics & $\begin{array}{l}\text { Lysergic acid diethylamide } \\
\text { (LSD), psilocybin }\end{array}$ & & None & $\begin{array}{l}\text { Treatment of cluster headache and of patients } \\
\text { with personality disorders, affective disorders } \\
\text { and adjustment disorders, and used to reduce } \\
\text { anxiety and pain in cancer patients. }\end{array}$ \\
\hline
\end{tabular}

The table does not list the variety of integrator's cocktails that are advertised in Internet as memory boosters. Abbreviations-AD: Alzheimer's disease; PD: Parkinson's disease; $\mathrm{MCl}$ : mild cognitive impairment;

AAMI: age-associated memory impairment. Numbers with MEM, CX or TC for special pharmaceuticals.

Table 4: Drugs for cognitive enhancement [138].

Instead, a complementary treatment schemes (e.g., CE by chess training with chess boards, chess books, building chess images, visual observation of chess games, vocational training with chess, metacognitive training, and additionally regular light physical stress) that would provide important, direct, and meaningful improvements for chess players cognition and maintain any level chess expertise
(Table 4).

\section{References}

1. http://www.dosb.de/en/organisa-tion/philosophie/sportdefinition

2. Dekhuijzen PN, Machiels HA, Heunks LM, van der Heijden HF, van Balkom RH (1999) Athletes and doping: effects of drugs on the respiratory system. Thorax 54: 1041-1046. 
3. http://www.spiegel.de/international/zeitgeist/outrage-over-Ivanchuk-the-greatchess-doping-scandal-a-595819.html

4. Hollinsky C, Maresch G, Hiller M, Kohlberger P, Bieglmayer C (1997) Beeinfluß körperliche Fitneß die Leistungsfähigkeit von Ranglistenschachspielern. Ö J Sportmed. 27: 51-59.

5. Hötting K, Röder B (2013) Beneficial effects of physical exercise on neuroplasticity and cognition. Neurosci Biobehav Rev 37: 2243-2257.

6. Kempermann G, Fabel K, Ehninger D, Babu H, Leal-Galicia P, et al. (2010) Why and how physical activity promotes experience-induced brain plasticity. Front Neurosci 4: 189.

7. Rowell LB, Taylor HL, Wang Y, Carlson Ws (1964) Saturation of arterial blood with oxygen during maximal exercise. J Appl Physiol 19: 284-286.

8. Brown AM, Ransom BR (2007) Astrocyte glycogen and brain energy metabolism. Glia 55: 1263-1271.

9. Gülin Öz, Seaquist ER, Kumar A, Criego AB, Benedict LE, et al. (2007) Human brain glycogen content and metabolism: implications on its role in brain energy metabolism. Am J Physiol Endocrinol Metabolism 292: 946-951.

10. Hultman E, Greenhaff PL (2000) Carbohydrate Metabolism in Exercise, in Nutrition in Sport. 85-96.

11. Gleeson M (2000) Biochemistry of exercise, in Nutrition in Sport. 17-38.

12. Dobbing J, Sands J (1973) Quantitative growth and development of human brain. Arch Dis Child 48: 757-767.

13. Quach TT, Rose C, Schwartz JC (1978) [3H] Glycogen hydrolysis in brain slices: responses to neurotransmitters and modulation of noradrenaline receptors. J Neurochem 30: 1335-1341.

14. Troubat N, GluckMAF, Tulppo M, Dugue B (2009) The stress of chess players as a model to study the effects of psychological stimuli on physiological responses: an example of substrate oxidation and heart rate variability in man. Eur J Appl Physiol 105: 343-349.

15. Cholerton B, Baker LD, Craft S (2013) Insulin, cognition, and dementia. Eur J Pharmacol 719: 170-179.

16. Husain M, Mehta MA (2011) Cognitive enhancement by drugs in health and disease. Trends Cogn Sci 15: 28-36.

17. BilaliÄ $\ddagger$ M, Smallbone K, McLeod P, Gobet F (2009) Why are (the best) women so good at chess? Participation rates and gender differences in intellectual domains. Proc Biol Sci 276: 1161-1165.

18. Chabris CF, Glickman ME (2006) Sex differences in intellectual performance: analysis of a large cohort of competitive chess players. Psychol Sci 17: 10401046.

19. Maass A, d'Ettole C, Cadinu M (2008) Checkmate? The role of gender stereotypes in the ultimate intellectual sport. Eur J Soc Psychol 38: 231-245.

20. http://www.merckmanuals.com/professional/appendixes/normal_laboratory_ values/blood_tests_normal_values.html\#v8508814

21. Zumoff B, Strain GW, Miller LK, Rosner W (1995) Twenty-Four-Hour Mean Plasma Testosterone Concentration Declines with Age in Normal Premenopausal Women. J Clin Endocrinol Metab 80: 1429-1430.

22. Feldman HA, Longcope C, Derby CA, Johannes CB, Araujo AB, et al. (2002) Age trends in the level of serum testosterone and other hormones in middleaged men: longitudinal results from the Massachusetts male aging study. J Clin Endocrinol Metab 87: 589-598.

23. Cunha TS, Tanno AP, Moura MJCS, Marcondes FK (2005) Relation between anabolic androgenic steroid administration, aerobic physical training and glycogen supercompensation Rev Bras Med Esporte 11: 180-184.

24. Lindqvist AS, Steenslandb PJ, Nybergb F, Fahlkea C (2002) Anabolic androgenic steroid affects competitive behaviour, behavioural response to ethanol and brain serotonin levels. Behav Brain Res 133: 21-29.

25. Rejeski WJ, Brubaker PH, Herb RA, Kaplan JR, Koritnik D (1988) Anabolic steroids and aggressive behavior in cynomolgus monkeys. J Behav Med 11: 95-105.

26. Johansson P, Hallberg M, Kindlundh A, Nyberg F (1999) The effects on opioid peptides after a single dose of amphetamine in rats pre-treated with anabolic androgenic steroids. Investigación Clínica \& Terapéutica 14: 4.

27. Mazur A, Booth A, Dabbs JM Jr (1992) Testosterone and Chess Competition.
Social Psychology Quarterly 55: 70-77.

28. Janowsky JS (2006) The role of androgens in cognition and brain aging in men Neuroscience 138: 1015-1020.

29. Cherrier MM, Asthana S, Plymate S, Baker L, Matsumoto AM, et al. (2001) Testosterone supplementation improves spatial and verbal memory in healthy older men. Neurology 57: 80-88.

30. Davison SL, Bell RJ, Gavrilescu M, Searle K, Maruff P, et al. (2011) Testosterone improves verbal learning and memory in postmenopausal women: Results from a pilot study. Maturitas 70: 307-311.

31. Frye CA, Park D, Tanaka M, Rosellini R, Svare B (2001) The testosterone metabolite and neurosteroid 3alpha-androstanediol may mediate the effects of testosterone on conditioned place preference. Psychoneuroendocrinology 26:731-750.

32. Azcoitia I, Sierra A, Veiga S, Honda S, Harada N, et al. (2001) Brain aromatase is neuroprotective. J Neurobiol 47: 318-329.

33. Frye CA, Rhodes ME, Dudek B (2005) Estradiol to aged female or male mice improves learning in inhibitory avoidance and water maze tasks. Brain Res 1036: 101-108.

34. Kanayama G, Hudson JI, Pope HG Jr (2008) Long-term psychiatric and medical consequences of anabolic-androgenic steroid abuse: a looming public health concern? Drug Alcohol Depend 98: 1-12.

35. Kanayama G, Kean J, Hudson JI, Pope HG Jr (2013) Cognitive deficits in longterm anabolic-androgenic steroid users. Drug Alcohol Depend 130: 208-214.

36. Grönbladh A (2013) Growth Hormone and Anabolic Androgenic Steroids: Effects on Neurochemistry and Cognition. Acta Universitatis Upsaliensis.

37. Choo JJ, Horan MA, Little RA, Rothwell NJ (1992) Anabolic effects of clenbuterol on skeletal muscle are mediated by beta 2-adrenoceptor activation. Am J Physiol 263: E50-56.

38. Emery PW, Rothwell NJ, Stock MJ, Winter PD (1984) Chronic effects of beta 2-adrenergic agonists on body composition and protein synthesis in the rat. Biosci Rep 4: 83-91.

39. Ramos BP, Colgan LA, Nou E, Arnsten AF (2008) Beta2 adrenergic agonist clenbuterol, enhances working memory performance in aging animals. Neurobiol Aging 29: 1060-1069

40. Barry AR, Graham MM (2014) Case report and review of clenbuterol cardiac toxicity Journal of Cardiology Cases 10: 121-162.

41. Pfleger H, Stocker K, Pabst H, Haralambie G (1980) [Sports medical examination of top class chess players (author's transI)]. MMW Munch Med Wochenschr 122: 1041-1044

42. Pfleger H, Metak G (1981) Sportmedizinische Untersuchungen an Schachspielern beim Schachmedizin-Turnier 1981. Herausgeber Deutscher Sportbund - Bundesausschuß Leistungssport.

43. Henke KG, Orenstein DM (1984) Oxygen saturation during exercise in cystic fibrosis. Am Rev Respir Dis 129: 708-711.

44. WEST JB, LAHIRI S, GILL MB, MILLEDGE JS, PUGH LG, et al. (1962) Arteria oxygen saturation during exercise at high altitude. J Appl Physiol 17: 617-621.

45. Hultman E, Harris RC (1988) Principles of Exercise Biochemistry. Karger 78119

46. Tanaka M, Ishii A, Shigihara Y, Tajima S, Funakura M, et al. (2012) Impaired Selective Attention Caused By Mental Fatigue. Journal of Neurological Sciences [Turkish] 29: 542-553

47. Newsholme EA, Blomstrand E, Ekblom B (1992) Physical and mental fatigue: metabolic mechanisms and importance of plasma amino acids. Br Med Bull 48: $477-495$

48. Goforth HW Jr, Laurent D, Prusaczyk WK Schneider KE, Petersen KF, et al. (2003) Effects of depletion exercise and light training on muscle glycogen supercompensation in men. Am J Physiol Endocrinol Metab 285: E1304-1311.

49. Soya H, Mukai A, Deocaris CC, Ohiwa N, Chang H, et al. (2007). Threshold like pattern of neuronal activation in the hypothalamus during treadmill running establishment of a minimum running stress (MRS) rat model. Neurosci Res 58: $341-348$

50. Soya H, Nakamura T, Deocaris CC, Kimpara A, limura M, et al. (2007) BDNF induction with mild exercise in the rat hippocampus. Biochem Biophys Res Commun 358: 961-967. 
51. Matsui T, Ishikawa T, Ito H, Okamoto M, Inoue K, et al. (2012) Brain glycogen supercompensation following exhaustive exercise. J Physiol 590: 607-616.

52. Peters A, Schweiger U, Pellerin L, Hubold C, Oltmanns KM, et al. (2004) The selfish brain: competition for energy resources. Neurosci Biobehav Rev 28: $143-180$

53. Bergström J, Hermansen L, Hultman E, Saltin B (1967) Diet, muscle glycogen and physical performance. Acta Physiol Scand 71: 140-150.

54. Pinter EJ, Patee CJ (1968) Fat-mobilizing action of amphetamine. J Clin Invest 47: 394-402.

55. Clarkson PM, Thompson HS (1997) Drugs and sport. Research findings and limitations. Sports Med 24: 366-384

56. Tikhomirov OK, Vinogradov YE (1970) Emotions in the heuristic function Soviet Psychology 8: 198-223.

57. Gobet $F$ (2012) Concepts without intuition lose the game: commentary on Montero and Evans (2011). Phenomenology and the Cognitive Sciences 11 : 237-250.

58. Hart CL, Marvin CB, Silver R, Smith EE (2012) Is cognitive functioning impaired in methamphetamine users? A critical review. Neuropsychopharmacology 37 $586-608$

59. Ilieva I, Boland J, Farah MJ (2013) Objective and subjective cognitive enhancing effects of mixed amphetamine salts in healthy people. Neuropharmacology 64 : 496-505.

60. Scott JC, Woods SP, Matt GE, Meyer RA, Heaton RK, et al. (2007) Neurocognitive effects of methamphetamine: a critical review and metaanalysis. Neuropsychol Rev 17: 275-297.

61. Grelotti DJ, Kanayama G, Pope HG Jr (2010) Remission of persisten methamphetamine-induced psychosis after electroconvulsive therapy: presentation of a case and review of the literature. Am J Psychiatry 167: 17-23.

62. Ho EL, Josephson SA, Lee HS, Smith WS (2009) Cerebrovascular complications of methamphetamine abuse. Neurocrit Care 10: 295-305.

63. http://tchibo.com/cb/790008/data/-/DerTchiboKaffeereport2012.pdf

64. Baker WJ, Theologus GC (1972) Effects of caffeine on visual monitoring. J App Psychol 56: 422-427.

65. Winston AP, Hardwick E, Jaberi N (2005) Neuropsychiatric effects of caffeine. Advances in Psychiatric Treatment 11: 432-439.

66. Adler GK (2000) Exercise and fatigue--is neuroendocrinology an importan factor? J Clin Endocrinol Metab 85: 2167-2169.

67. Spriet LL, MacLean DA, Dyck DJ, Hultman E, Cederblad G, et al. (1992) Caffeine ingestion and muscle metabolism during prolonged exercise in humans. Am J Physiol 262: E891-898.

68. Smith A (2002) Effects of caffeine on human behavior. Food Chem Toxicol 40: $1243-1255$

69. Jabbar SB, Hanly MG (2013) Fatal Caffeine Overdose: A Case Report and Review of Literature. Am J Forensic Med Pathol 34: 321-324.

70. http://www.iom.edu/ /media/Files/Activity \%20Files/Nutrition/ PotentialEffectsofCaffeine/caffeineORNLreport.pdf

71. Nawrot P, Jordan S, Eastwood J, Rotstein J, Hugenholtz A, et al. (2003) Effects of caffeine on human health. Food Addit Contam 20: 1-30.

72. Dollery C (1999) Therapeutic drugs. Edinburgh: Churchill Livingstone.

73. Stein EA, Pankiewicz J, Harsch HH, Cho JK, Fuller SA, et al. (1998) Nicotineinduced limbic cortical activation in the human brain: a functional MRI study. Am J Psychiatry 155: 1009-1015.

74. Devinsky O, D. Luciano (1993) The contributions of cingulate cortex to human behavior. Neurobiology of Cingulate Cortex and Limbic Thalamus 527-556.

75. Niemegeers P, Dumont GJ, Quisenaerts C, Morrens M, Boonzaier J (2014) The effects of nicotine on cognition are dependent on baseline performance. Eur Neuropsychopharmacol 24: 1015-1023.

76. Newhouse PA, Potter A, Singh A (2004) Effects of nicotinic stimulation on cognitive performance. Curr Opin Pharmacol 4: 36-46.

77. Solarino B, Rosenbaum F, Riesselmann B, Buschmann CT, Tsokos M (2010) Death due to ingestion of nicotine-containing solution: case report and review of the literature. Forensic Sci Int 195: e19-22.
78. Pilgrim $\mathrm{JL}$, Woodford N, Drummer OH (2013) Cocaine in sudden and unexpected death: a review of 49 post-mortem cases. Forensic Sci Int 227 $52-59$

79. Degenhardt L, Singleton J, Calabria B, McLaren J, Kerr T, et al. (2011) Mortality among cocaine users: a systematic review of cohort studies. Drug Alcohol Depend 113: 88-95.

80. Bracken ME, Bracken DR, Nelson AG, Conlee RK (1988) Effect of cocaine on exercise endurance and glycogen use in rats. J Appl Physiol (1985) 64: 884-887.

81. Evans P, Persinger MA (2010) Erythropoietin and mild traumatic brain injury: neuroprotective potential and dangerous side-effect. J Biol Sciences 10: 739746.

82. Bennett CL, Spiegel DM, Macdougall IC, Norris L, Qureshi ZP, et al. (2012) A review of safety, efficacy, and utilization of erythropoietin, darbepoetin, and peginesatide for patients with cancer or chronic kidney disease: a report from the Southern Network on Adverse Reactions (SONAR). Semin Thromb Hemost 38: 783-796.

83. Vijayakumar A, Novosyadlyy R, Wu Y, Yakar S, LeRoith D (2010) Biological effects of growth hormone on carbohydrate and lipid metabolism. Growth Horm IGF Res 20: 1-7.

84. Møller N, Jørgensen JO, Abildgård N, Orskov L, Schmitz O, et al. (1991) Effects of growth hormone on glucose metabolism. Horm Res 36 Suppl 1: 32-35.

85. Liu H, Bravata DM, Olkin I, Friedlander A, Liu V, et al. (2008) Systematic Review: The Effects of Growth Hormone on Athletic Performance. Ann Intern Med 148: 747-758.

86. Meinhardt U, Nelson AE, Hansen JL, Birzniece V, Clifford D, et al. (2010) The effects of growth hormone on body composition and physical performance in recreational athletes: a randomized trial. Ann Intern Med 152: 568-577.

87. Castro JR, Costoya JA, Gallego R, Prieto A, Arce VM, et al. (2000) Expression of growth hormone receptor in the human brain. Neurosci Lett 281: 147-150.

88. David Aberg N, Lind J, Isgaard J, Georg Kuhn H (2010) Peripheral growth hormone induces cell proliferation in the intact adult rat brain. Growth Horm IGF Res 20: 264-269.

89. Nyberg F (2000) Growth hormone in the brain: characteristics of specific brain targets for the hormone and their functional significance. Front Neuroendocrinol 21: $330-348$.

90. Falleti MG, Maruff P, Burman P, Harris A (2006) The effects of growth hormone $(\mathrm{GH})$ deficiency and $\mathrm{GH}$ replacement on cognitive performance in adults: a meta-analysis of the current literature. Psychoneuroendocrinology 31: 681-691.

91. High WM Jr, Briones-Galang M, Clark JA, Gilkison C, Mossberg KA, et al. (2010) Effect of Growth Hormone Replacement Therapy on Cognition after Traumatic Brain Injury. J Neurotrauma 27: 1565-1575.

92. Leon-Carrion J, Martin-Rodriguez JF, Madrazo-Atutxa A, Soto-Moreno A Venegas-Moreno E, et al. (2010) Evidence of Cognitive and Neurophysiological Impairment in Patients with Untreated Naïve Acromegaly. J Clin Endocrinol Metab 95: 4367-4379.

93. Dominici FP, Balbis A, Bartke A, Turyn D (1998) Role of hyperinsulinemia on hepatic insulin receptor concentration and autophosphorylation in the presence of high growth hormone levels in transgenic mice overexpressing growth hormone gene. J Endocrinol 159: 15-25.

94. Behan LA, Monson JP, Agha A (2011) The interaction between growth hormone and the thyroid axis in hypopituitary patients. Clin Endocrinol (Oxf) 74: 281-288.

95. Mercola KE, Cline MJ, Golde DW (1981) Growth hormone stimulation of normal and leukemic human T-lymphocyte proliferation in vitro. Blood 58: 337-340.

96. Takala J, Ruokonen E, Webster NR, Nielsen MS, Zandstra DF, et al. (1999) Increased mortality associated with growth hormone treatment in critically ill adults. N Engl J Med 341: 785-792.

97. Simpson HL, Umpleby AM, Russell-Jones DL (1998) Insulin-like growth factorand diabetes. A review. Growth Horm IGF Res 8: 83-95.

98. Russell-Jones DL, Umpleby AM, Hennessy TR, Bowes SB, Shojaee-Moradie F et al. (1994) Use of a leucine clamp to demonstrate that IGF-I stimulates protein synthesis in normal humans. Am J Physiol 267: E591-E598.

99. Aleman A, Verhaar HJ, De Haan EH, De Vries WR, Samson MM, et al. (1999) Insulin-like growth factor-I and cognitive function in healthy older men. J Clin Endocrinol Metab 84: 471-475. 
100.van Dam PS, Aleman A, de Vries WR, Deijen JB, van der Veen EA, et al. (2000) Growth hormone, insulin-like growth factor I and cognitive function in adults. Growth Horm IGF Res 10 Suppl B: S69-73.

101.Sonntag WE, Ramsey M, Carter CS (2005) Growth hormone and insulin-like growth factor-1 (IGF-1) and their influence on cognitive aging. Ageing Res Rev 4: 195-212.

102. Torres-Aleman I (2010) Toward a comprehensive neurobiology of IGF-I. Dev Neurobiol 70: 384-396

103. Adams GR (2002) Invited Review: Autocrine/paracrine IGF-I and skeletal muscle adaptation. J Appl Physiol (1985) 93: 1159-1167.

104. Renehan AG, Zwahlen M, Minder C, O'Dwyer ST, Shalet SM, et al. (2004) Insulin-like growth factor (IGF)-I, IGF binding protein-, and cancer risk: systematic review and meta-regression analysis. Lancet 363: 1346-1353.

105. Handelsman DJ (2006) Clinical review: The rationale for banning human chorionic gonadotropin and estrogen blockers in sport. J Clin Endocrinol Metab 91: 1646-1653.

106. Stenman UH, Hotakainen K, Alfthan H (2008) Gonadotropins in doping: pharmacological basis and detection of illicit use. $\mathrm{Br} \mathrm{J}$ Pharmacol 154: 569 583.

107. Allan CA, McLachlan RI (2004) Age-related changes in testosterone and the role of replacement therapy in older men. Clin Endocrinol (Oxf) 60: 653-670.

108. Birge SJ, McEwen BS, Wise PM (2001) Effects of estrogen deficiency on brain function. Implications for the treatment of postmenopausal women. Postgrad Med Spec No: 11-16.

109. Beauchet O (2006) Testosterone and cognitive function: current clinical evidence of a relationship. Eur J Endocrinol 155: 773-781.

110. Bryan KJ, Mudd JC, Richardson SL, Chang J, Lee HG (2010) Down-regulation of serum gonadotropins is as effective as estrogen replacement at improving menopause-associated cognitive deficits. J Neurochem 112: 870-881.

111. Lukacs H, HiattES, LeiZM, Rao CV (1995)Peripheral and intracerebroventricular administration of human chorionic gonadotropin alters several hippocampus associated behaviors in cycling females. Horm Behav 29: 42-58.

112. Lei ZM, Rao CV, Kornyei JL, Licht P, Hiatt ES (1993) Novel expression of human chorionic gonadotropin/luteinizing hormone receptor gene in brain. Endocrinology 132: 2262-2270.

113. Kawas C, Resnick S, Morrison A, Brookmeyer R, Corrada M (1997) A prospective study of estrogen replacement therapy and the risk of developing Alzheimer's disease: the Baltimore Longitudinal Study of Aging. Neurology 48: 1517-1521.

114. Casadesus G, Milliken EL, Webber KM, Bowen RL, Lei Z, et al. (2008) Increases in luteinizing hormone are associated with declines in cognitive performance. Mol Cell Endocrinol 269: 107-111.

115. Berry A, Tomidokoro Y, Ghiso J, Thornton J (2008) Human chorionic gonadotropin (a luteinizing hormone homologue) decreases spatial memory and increases brain amyloid-? levels in female rats. Horm Behav 54: 143-152.

116. D'Agata R, Vicari E, Romeo F, Aliffi A, Gulizia S (1979) Male Hypogonadism Associated with Elevated LH, Normal FSH and Low Testosterone Possibly Due to an Abnormal LH Molecule. International Journal of Andrology 2: 482488.

117. Wahjoepramono EJ (2012) Cognitive Impairement in Central Hypogonadism in Male Associated with Pituitary Tumor. Medicinus 3.

118. Newsholme EA, Dimitriadis G (2001) Integration of biochemical and physiologic effects of insulin on glucose metabolism. Exp Clin Endocrino Diabetes 109 Suppl 2: S122-134

119. Duarte Al, Moreira PI, Oliveira CR (2012) Insulin in central nervous system: more than just a peripheral hormone. J Aging Res 2012: 384017.

120.Avinash M (2012) Advanced and Recent Emerging Trends in Insulin Drug Delivery Systems. International Journal of Bio-Pharma Research 1.

121. Gonder-Frederick LA, Clarke WL, Cox DJ (1997) The Emotional, Social, and Behavioral Implications of Insulin-Induced Hypoglycemia. Semin Clin Neuropsychiatry 2: 57-65.

122. Konrad C, Schüpfer G, Wietlisbach M, Gerber H (1998) [Insulin as an anabolic: hypoglycemia in the bodybuilding world]. Anasthesiol Intensivmed Notfallmed Schmerzther 33: 461-463.
123. Edge JA, Ford-Adams ME, Dunger DB (1999) Causes of death in children with insulin dependent diabetes 1990-96. Arch Dis Child 81: 318-323.

124. Holmes GL, Weber DA (1986) Effects of ACTH on seizure susceptibility in the developing brain. Ann Neurol 20: 82-88.

125.Dunn AJ, Willem HG (1977) How ACTH acts on the brain Biobehavioral Reviews 1: 15-23.

126. Simmons PS, Miles JM, Gerich JE, Haymond MW (1984) Increased proteolysis. An effect of increases in plasma cortisol within the physiologic range. J Clin Invest 73: 412-420.

127. Coderre L, Srivastava AK, Chiasson JL (1991) Role of glucocorticoid in the regulation of glycogen metabolism in skeletal muscle. Am J Physiol 260: E927932.

128. Waltman C, Blackman MR, Chrousos GP, Riemann C, Harman SM (1991) Spontaneous and glucocorticoid-inhibited adrenocorticotropic hormone and cortisol secretion are similar in healthy young and old men. J Clin Endocrinol Metab 73: 495-502

129. Stawski RS, Almeida DM, Lachman ME, Tun PA, Rosnick CB, et al. (2011) Associations Between Cognitive Function and Naturally Occurring Daily Cortisol During Middle Adulthood: Timing Is Everything. J Gerontol B Psychol Sci Soc 66: i71-i81.

130. MacLullich AM, Deary IJ, Starr JM, Ferguson KJ, Wardlaw JM, et al. (2005) Plasma cortisol levels, brain volumes and cognition in healthy elderly men. Psychoneuroendocrinology 30: 505-515.

131.Porter RJ, Barnett NA, Idey A, McGuckin EA, O'Brien JT (2002) Effects of hydrocortisone administration on cognitive function in the elderly. $J$ Psychopharmacol 16: 65-71.

132.Lupien S, Lecours AR, Lussier I, Schwartz G, Nair NP, et al. (1994) Basal cortisol levels and cognitive deficits in human aging. J Neurosci 14: 2893 2903

133. Kopell BS, Wittner WK, Lunde D, Warrick G, Edwards D (1970) Cortisol effects on averaged evoked potentials, alpha-rhythm, time estimation, and two-flash fusion threshold. Psychosom Med 32: 39-49.

134.Diamond DM, Bennett MC, Fleshner M, Rose GM (1992) Inverted-U relationship between the level of peripheral corticosterone and the magnitude of hippocampal primed burst potentiation. Hippocampus 2: 421-430.

135. Squire LR (1992) Memory and the hippocampus: a synthesis from findings with rats, monkeys, and humans. Psycho1 Rev 99: 195-231.

136. Graf P, Schacter DL (1985) Implicit and explicit memory for new associations in normal and amnesic subjects. J Exp Psychol Learn Mem Cogn 11: 501-518.

137. Schäcke H, Döcke WD, Asadullah K (2002) Mechanisms involved in the side effects of glucocorticoids. Pharmacol Ther 96: 23-43.

138. Lanni C, Lenzken SC, Pascale A, Del Vecchio I, Racchi M, et al. (2008) Cognition enhancers between treating and doping the mind. Pharmacol Res 57: 196-213.

139. Gobet FN, Charness N (2006) Chess and games. Cambridge handbook on expertise and expert performance. Cambridge, MA: Cambridge, University Press 523-538.

140. Grabner $\mathrm{RH}$ (2014) The role of intelligence for performance in the prototypical expertise domain of chess. Intelligence $45: 26-33$.

141. Charness N (1992) The impact of chess research on cognition science. Psychol Res 54: 4-9.

142. Howard RW (2005) Are gender differences in high achievement disappearing? A test in one intellectual domain. J Biosoc Sci 37: 371-380.

143.van der Maas HL, Wagenmakers EJ (2005) A psychometric analysis of chess expertise. Am J Psychol 118: 29-60.

144. Charness N, Tuffiash M, Jastrzembski T (2004) Motivation, emotion, and cognition: Integrative perspectives Mahwah, NJ: Erlbaum 2004: 299-319.

145. Goldin SE (1979) Recognition memory for chess positions: Some preliminary research. The American Journal of Physiology 92: 19-31.

146. Bilalic M, McLeod P (2006) How intellectual is chess? -- a reply to Howard. J Biosoc Sci 38: 419-421.

147. Bilalic M, McLeod P, Gobet F (2007) Does chess need intelligence? - A study with young chess players. Intelligence $35: 457-470$. 
148. Vidudic V, Simundic S, Vidudic LJ, Boras D (2009) Information Model For The Enhancement Of Human Intelligence, for the Period 2009 - 2020. Proceedings of the 9th WSEAS International Conference on APPLIED INFORMATICS AND COMMUNICATIONS (AIC ‘09).

149. Maher B (2008) Poll results: look who's doping. Nature 452: 674-675.

150. Dietz P, Striegel H, Franke AG, Lieb K, Simon P, et al. (2013) Randomized response estimates for the 12-month prevalence of cognitive-enhancing drug use in university students. Pharmacotherapy 33: 44-50.

151. Kraus MS, Keefe RS (2007) Cognition as an outcome measure in schizophrenia. Br J Psychiatry Suppl 50: s46-51.

152. Keefe RS, Malhotra AK, Meltzer HY, Kane JM, Buchanan RW, et al. (2008) Efficacy and safety of donepezil in patients with schizophrenia or schizoaffective disorder: significant placebo/practice effects in a 12-week, randomized double-blind, placebo-controlled trial. Neuropsychopharmacology 33: 12171228 .

153. Cools R, Frank MJ, Gibbs SE, Miyakawa A, Jagust W, et al. (2009) Striatal dopamine predicts outcome-specific reversal learning and its sensitivity to dopaminergic drug administration. J Neurosci 29: 1538-1543.

154. Mehta MA, Owen AM, Sahakian BJ, Mavaddat N, Pickard JD, et al. (2000) Methylphenidate enhances working memory by modulating discrete frontal and parietal lobe regions in the human brain. J Neurosci 20: RC65.

155. Teicher MH, Polcari A, Anderson CM, Andersen SL, Lowen SB, et al. (2003) Rate dependency revisited: understanding the effects of methylphenidate in children with attention deficit hyperactivity disorder. J Child Adolesc Psychopharmacol 13: 41-51.

156. Finke K, Dodds CM, Bublak P, Regenthal R, Baumann F, et al. (2010) Effects of modafinil and methylphenidate on visual attention capacity: a TVA-based study. Psychopharmacology (Berl) 210: 317-329.

157.Randall DC, Shneerson JM, File SE (2005) Cognitive effects of modafinil in student volunteers may depend on IQ. Pharmacol Biochem Behav 82: 133139.

158. Kimberg DY, D'Esposito M, Farah MJ (1997) Effects of bromocriptine on human subjects depend on working memory capacity. Neuroreport 8: 3581 3585.

159. Grefkes C, Wang LE, Eickhoff SB, Fink GR (2010) Noradrenergic modulation of cortical networks engaged in visuomotor processing. Cereb Cortex 20: 783797.

160. Frank MJ, O'Reilly RC (2006) A mechanistic account of striatal dopamine function in human cognition: psychopharmacological studies with cabergoline and haloperidol. Behav Neurosci 120: 497-517.

161. Gibbs SE, D’Esposito M (2005) Individual capacity differences predict working memory performance and prefrontal activity following dopamine receptor stimulation. Cogn Affect Behav Neurosci 5: 212-221.

162.Pilling S, Bebbington P, Kuipers E, Garety P, Geddes J, et al. (2002) Psychological treatments in schizophrenia: II. Meta-analyses of randomized controlled trials of social skills training and cognitive remediation. Psychol Med 32: 783-791.

163. Kurtz MM, Moberg PJ, Gur RC, Gur RE (2001) Approaches to cognitive remediation of neuropsychological deficits in schizophrenia: a review and meta-analysis. Neuropsychol Rev 11: 197-210.

164.Suslow T, Schonauer K, Arolt V (2001) Attention training in the cognitive rehabilitation of schizophrenic patients: a review of efficacy studies. Acta Psychiatr Scand 103: 15-23.

165. Krabbendam L, Aleman A (2003) Cognitive rehabilitation in schizophrenia: a quantitative analysis of controlled studies. Psychopharmacology (Berl) 169: 376-382.

166. Twamley EW, Jeste DV, Bellack AS (2003) A review of cognitive training in schizophrenia. Schizophr Bull 29: 359-382.

167. McGurk SR, Twamley EW, Sitzer DI, McHugo GJ, Mueser KT (2007) A metaanalysis of cognitive remediation in schizophrenia. Am J Psychiatry 164: 1791
1802.

168. Larøi F, Raballo A (2010) Notes from Underground: Are Cognitive-Enhancing Drugs Respecting their Promises? Front Psychol 1: 158

169. Larøi F, Van der Linden M (2007) Revalidation cognitive et schizophrénie: pour une approche individualisée et centrée sur les activités de la vie quotidienne. Lett Psychiatre 3: 50-53.

170.Levaux MN, Vezzaro J, Larøi F, Offerlin-Meyer I, Danion JM, et al. (2009) Cognitive rehabilitation of the updating sub-component of working memory in schizophrenia: a case study. Neuropsychol Rehabil 19: 244-273.

171. Medalia A, Choi J (2009) Cognitive remediation in schizophrenia. Neuropsychol Rev 19: 353-364.

172. Couture SM, Penn DL, Roberts DL (2006). The functional significance of social cognition in schizophrenia: a review. Schizophr Bull 32: 44-63.

173. Penn DL, Sanna LJ, Roberts DL (2008) Social cognition in schizophrenia: an overview. Schizophr Bull 34: 408-411.

174. Wezenberg E, Verkes RJ, Sabbe BG, Ruigt GS, Hulstijn W (2005) Modulation of memory and visuospatial processes by biperiden and rivastigmine in elderly healthy subjects. Psychopharmacology (Berl) 181: 582-594.

175. Mehta MA, Swainson R, Ogilvie AD, Sahakian J, Robbins TW (2001) Improved short-term spatial memory but impaired reversal learning following the dopamine $D(2)$ agonist bromocriptine in human volunteers. Psychopharmacology (Berl) 159: 10-20.

176. Swainson R, Rogers RD, Sahakian BJ, Summers BA, Polkey CE, et al. (2000) Probabilistic learning and reversal deficits in patients with Parkinson's disease or frontal or temporal lobe lesions: possible adverse effects of dopaminergic medication. Neuropsychologia 38: 596-612.

177. Dagher A, Robbins TW (2009) Personality, addiction, dopamine: insights from Parkinson's disease. Neuron 61: 502-510.

178. Weintraub D, Siderowf AD, Potenza MN, Goveas J, Morales KH, et al (2006) Association of dopamine agonist use with impulse control disorders in Parkinson disease. Arch Neurol 63: 969-973.

179. Weintraub D, Koester J, Potenza MN, Siderowf AD, Stacy M, et al. (2010) Impulse control disorders in Parkinson disease: a cross-sectional study of 3090 patients. Arch Neurol 67: 589-595.

180. Voon V, Fernagut PO, Wickens J, Baunez C, Rodriguez M, et al. (2009) Chronic dopaminergic stimulation in Parkinson's disease: from dyskinesias to impulse control disorders. Lancet Neurol 8: 1140-1149.

181. Bilder RM, Volavka J, Lachman HM, Grace AA (2004) The catechol-O methyltransferase polymorphism: relations to the tonic-phasic dopamine hypothesis and neuropsychiatric phenotypes. Neuropsychopharmacology 29 . 1943-1961.

182. Varsaldi F, Miglio G, Scordo MG, Dahl ML, Villa LM, et al. (2006) Impact of the CYP2D6 polymorphism on steady-state plasma concentrations and clinical outcome of donepezil in Alzheimer's disease patients. Eur J Clin Pharmaco 62: 721-726.

183. Cacabelos R, Llovo R, Fraile C, Fernández-Novoa L (2007) Pharmacogenetic aspects of therapy with cholinesterase inhibitors: the role of CYP2D6 in Alzheimer's disease pharmacogenetics. Curr Alzheimer Res 4: 479-500. 